\title{
Levying VAT in the EU Customs Union: Towards a Single Indirect Tax Area? The Ordeal of Indirect Tax Harmonisation
}

\author{
Ben Terra*
}

\section{Abstract}

This contribution deals with the latest proposals regarding levying VAT in the European Union (EU) Customs Union. The present system, which has been in place since 1993 and was supposed to be transitional, splits every cross-border transaction into an exempted cross-border supply and a taxable cross-border acquisition. It is like a customs system, but lacks equivalent controls and is therefore the root of crossborder fraud. After many years of unsuccessful attempts, the Commission abandoned the objective of implementing definitive VAT arrangements based on the principle of taxing all cross-border supplies of goods in the Member State of their origin, under the same conditions that apply to domestic trade including VAT rates. The European Parliament and the Council agreed that the definitive system should be based on the principle of taxation in the Member State of the destination of the goods. After a brief discussion of the VAT Action Plan of 2016 (Section 1), the e-commerce package in the form of Directive (EU) 2017/2455 is dealt with (Section 2), followed by the proposal to harmonise and simplify certain rules in the VAT system and introduce the definitive system, only partially adopted (Section 3). Section 4 deals with the proposal to introduce detailed measures of the definitive VAT system. The proposed harmonisation and simplification of certain rules were meant to become applicable on 1 January 2019, but will become only partially applicable on 2020. It is proposed to make the detailed measures of the definitive VAT system applicable in 2022. It remains to be seen whether the Member States are willing to accept the definitive VAT system at all; hence the subtitle 'the ordeal of indirect tax harmonisation'.

Keywords: single indirect tax area, VAT action plan, quick fixes, e-commerce package, definitive VAT system

\section{The VAT Action Plan, 2016}

On 7 April 2016, the Commission presented its action plan on VAT, laying out the pathway to the creation of a single EU VAT area. ${ }^{1}$

The Commission noted that the common VAT system is a core element of Europe's single market. By removing obstacles that distorted competition and prevented the free movement of goods, it has facilitated trade within the single market. It is a major and growing source of revenue in the EU, raising almost EUR 1 trillion in 2014, which corresponds to 7\% of the GDP of the EU. One of the EU's own resources is also based on VAT. As a broad-based consumption tax, it is one of the most growth-friendly forms of taxation. But the VAT system has been unable to keep pace with the challenges of today's global, digital and mobile economy. The current VAT system, which was intended to be a transitional system, is fragmented, complex for the growing number of businesses operating cross-border and leaves the door open to fraud: domestic and cross-border transactions are treated differently, and goods or services can be bought free of VAT within the single market. Reform is urgently needed.

The action plan consists of four building blocks:

1. Fight against fraud with conventional measures: the role of the European Commission is to facilitate work and cooperation between EU Member States;

2. Definitive VAT system: Treatment of intra-EU supplies - key principles for a future single European VAT system;

3. E-commerce and small and medium-sized enterprises (SMEs): establish level playing field between e-commerce and traditional trade, and make life easier for $\mathrm{SMEs} ;{ }^{2}$

1. $\operatorname{COM}(2016) 148$, "Communication from the Commission to the European Parliament, the Council and the European Economic and Social Committee on an action plan on VAT Towards a single EU VAT area Time to decide".

2. This contribution presents a detailed discussion on the e-Commerce Package (see Section 2), but does not discuss the proposals as regards the special scheme for SMEs. We note that on 18 February 2020, finance ministers have agreed to new simplification rules which will open the VAT exemption to small businesses established in other member states and help reduce VAT compliance costs. The new VAT scheme for SMEs will apply as of 1 January 2025. 
4. New approach on VAT rates: in destination-based system, less need for harmonisation of rates. ${ }^{3}$

\subsection{Fight against Fraud with Conventional Measures}

The current levels of VAT gap (i.e. the difference between the expected VAT revenues and what is actually collected by the national tax authorities) call for urgent action on three fronts: achieving better administrative cooperation, i.e. improving cooperation within the EU and with non-EU countries, improving voluntary compliance and collectively improving the performance of European tax administrations. ${ }^{4}$ In addition, the boom in e-commerce requires a new approach to tax collection.

\subsection{The Definitive VAT System}

The Commission plans to present a legislative proposal to put in place a definitive VAT system. This definitive system will rest upon the agreement among EU legislators that the VAT system should be based on the principle of taxation in the country of destination of the goods. This means that the taxation rules according to which the supplier of goods collects VAT from his customer will be extended to cross-border transactions. This change alone should help reduce cross-border VAT fraud by EUR 40 billion per year.

Some significant simplification measures need to be taken to accompany this change. For instance, the OneStop Shop, which already exists for telecommunication, broadcasting and electronic services and which is due to be extended to all e-commerce transactions, will be even more widely implemented and rebooted so as to fully exploit the opportunities presented by digital technology to simplify, standardise and modernise processes. Businesses will need to register for VAT purposes only in the Member States where they were established. Collectively, businesses should save an average of around EUR 1 billion.

As a first legislative step, the principle of taxation of cross-border supplies will be re-established and the One-Stop Shop extended to cover cross-border B2B supplies of goods; see Sections 2 and 3. However, compliant businesses, certified by their tax administrations, including SMEs, would continue to be liable for VAT on goods purchased from other EU countries; see Section 3.2. As compliant businesses represent the vast majority of taxable persons involved in cross-border transactions, this would significantly reduce the amounts of VAT channelled through the One-Stop Shop and would make it easier for businesses to adapt.

As a second legislative step, taxation would cover all cross-border supplies so all supplies in goods and ser-

3. This contribution does not entail a detailed discussion on the new approach on VAT rates. A high-level overview is presented in Section 1.4. For a more detailed discussion, see, inter alia, Madeleine Merkx, John Gruson, Definitive VAT Regime: Ready for the Next Step?, EC Tax Review, Volume 28, Issue 3, pp. 147-148

4. See also the Special Report No 24/2015 - "Tackling intra-Community VAT fraud: More action needed" adopted by the European Court of Auditors on 15 December 2015. vices within the single market, either domestic or crossborder, would be treated the same.

\subsection{Removing VAT Obstacles to e-Commerce in the Single Market}

The Commission announced a legislative proposal to modernise and simplify VAT for cross-border e-commerce, in particular for SMEs. This will include:

- extending the One-Stop-Shop mechanism to EU and non-EU countries' online sales of tangible goods to final consumers; see Section 2.2;

- introducing a common EU-wide simplification measure (VAT threshold under which no registration in other Member States or to the One-Stop Shop is required for cross-border supplies) to help small start-up e-commerce businesses; see Section 2.1.2;

- removing the VAT exemption for imports of small consignments from non-EU suppliers; see Section 2.2.3.11.

\subsection{New Approach on VAT Rates}

At the same time the Commission announced that taxation at destination would grant Member States more flexibility in setting VAT rates and that all currently (2016) existing reduced rates, including derogations, legally applied in Member States should be maintained and could be made available to all Member States, ensuring equal treatment.

Two policy options were considered that address the expiry of derogations to allow the definitive VAT system to enter into force, in addition to a standard rate of not less than $15 \%$. The first option would grant existing derogations to all Member States by integrating what are the national provisions in the VAT Directive. The second option would address the issue of derogations by removing the constraints that created the need for such derogations, namely the list of goods and services to which reduced VAT rates can be applied (Annex III) and the 5\% minimum for additional reduced rates. It would substitute the current (at the time of writing) principle, whereby reduced rates can be introduced only if specifically allowed, with the principle that a limited number of reduced rates are allowed on any supply of goods or services unless this is specifically excluded.

On 18 January 2018, the Commission presented its 'Proposal for a Council Directive amending Directive 2006/112/EC as regards rates of value added tax ${ }^{5}$ from which we derive that the first option mentioned earlier was considered to be too complex from a technical legal viewpoint and could create future conflicts with the fiscal neutrality principle and that the second option is the preferred option, at least as far as the Commission is concerned. ${ }^{6}$

5. $\operatorname{COM(2018)~20.~See~also~Commission~staff~working~document:~Impact~}$ Assessment Accompanying the document Proposal for a Council Directive amending Directive 2006/112/EC as regards rates of value added tax. SWD(2018) 7 final. Not further discussed here.

6. It remains questionable to what extent the EU has legislative competence to approve disharmonising VAT legislation, see Rita de la Feria, 


\section{The e-Commerce Package; Council Directive (EU) $2017 / 2455$}

On 5 December 2017, the Council adopted Directive (EU) 2017/2455 amending Directive 2006/112/EC and Directive 2009/132/EC as regards certain value added tax obligations for supplies of services and distance sales of goods. ${ }^{7}$ The Directive distinguishes between amendments to the VAT Directive with effect from 1 January 2019 (no IT impact) - see Section 2.1.2 - and amendments with effect from 1 January 2021 (with IT impact) - see Section 2.2. On the same date, the Council adopted Regulation (EU) 2017/2459; ${ }^{8}$ see Section 2.1.1 and Regulation (EU) No 2017/2454 amending Regulation (EU) No 904/2010, ${ }^{9}$ see Section 2.2.3.12.

\subsection{Amendments to Implementing Regulation and to the VAT Directive with Effect from 1 January 2019}

Regulation (EU) 2017/2459 replaced Article 24b of Implementing Regulation (EU) No 282/2011; see Section 2.1.1. Directive (EU) 2017/2455 replaced Article 58 (see Section 2.1.2), Article 219 (see Section 2.1.3), Article 358a point (1) and Article 361(1) point (e); see Section 2.1.4.

\subsubsection{Requirement for One Piece of Evidence Threshold of EUR 100,000}

On 21 June 2013, the Council adopted Regulation (EU) No. $1042 / 2013^{10}$ amending implementing Regulation (EU) No. 282/2011 as regards the place of supply services, especially of telecommunications, radio and television broadcasting services and electronic services to non-taxable persons (hereinafter referred to as TBE services).

Articles 24a-24f of the Regulation, inserted by Regulation (EU) No. 1042/2013, introduced a series of presumptions for customer location.

According to Article 24a, where a supplier of TBE services provides those services at a location such as a telephone kiosk, a Wi-Fi hot spot, an Internet café, a restaurant or a hotel lobby where the physical presence of the recipient of the service at that location is needed for the service to be rendered to him by that supplier, the presumption shall be that, for the application of Article 44 (main rule of supply of services to taxable persons), Article 58 (supplier of TBE services to non-taxable per-

Max Schofield, Towards an [Unlawful] Modernized EU VAT Rate Policy, EC Tax Review, Volume 26, Issue 2, pp. 89-95.

7. OJ 2017, L 348, p. 7. See also $\operatorname{COM}(2016) 757$ final: Modernising VAT for cross-border B2C e-commerce, Proposal for a Council Directive amending directive 2006/112/EC and directive 2009/132/EC as regards certain value added tax obligations for supplies of services and distance sales of goods. See also documents SWD(2016) 379 final and $\operatorname{SWD}(2016) 382$ final.

8. OJ 2017, L 348, p. 32. For the proposal see $\operatorname{COM(2016)~} 756$.

9. OJ 2017, L 348, pp. 1-6.

10. OJ 2013, L 284, p. 1. sons) and Article 59a (effective use and enjoyment) of the VAT Directive, the customer is established, has his permanent address or usually resides at the place of that location and the service is effectively used and enjoyed there. (If the location referred to above is on board a ship, aircraft or train carrying out a passenger transport operation within the Community, the country of the location is the country of departure of the passenger transport operation.)

According to Article 24b, point (d), where the services are supplied under circumstances other than those referred to in Article 24a, the general presumption will be that the customer is established, has his permanent address or usually resides at the place identified as such by the supplier using two pieces of non-contradictory evidence as listed in Article 24f of the Regulation. Article 24(1) provides that the supplier may rebut the presumption in Article 24a regarding the supplier to non-taxable persons, where he has three pieces of non-contradictory evidence indicating that the customer is established, has his permanent address or usually resides elsewhere. A tax administration may also rebut the presumption made under Article 24a, where there are indications of misuse or abuse by the supplier (see Art. 24d(2)).

For TBE services supplied to a non-taxable person via his fixed land line, through mobile networks or using a decoder or similar device or a vieming card, the presumption is that, for the application of Article 58 of the VAT Directive, the customer is established, has his permanent address or usually resides at the place of installation of the fixed landline (Art. 24b, point (a)), in the country identified by the mobile country code of the SIM card used when receiving those services (Art. 24b, point (b)) or at the place where that decoder or similar device is located, or if that place is not known, the place to which the viewing card is sent with a view to being used there (Art. 24b, pint (c)). According to Article 24b, point (d), where the services are supplied to a non-taxable person under circumstances other than those referred to in points (a) to (c) ${ }^{11}$ the general presumption will be that the customer is established, has his permanent address or usually resides at the place identified as such by the supplier using two pieces of non-contradictory evidence as listed in Article $24 \mathrm{f}$ of the regulation.

The requirement, laid down in Article $24 b(d)$, that the supplier of TBE services to non-taxable persons has to collect two items of non-contradictory evidence of the place of establishment of his customers, is extremely burdensome for businesses, SMEs in particular. This is because their business flow and volume are not important enough to invest in costly technological solutions allowing them to obtain two forms of proof of the customer location.

Implementing Regulation (EU) 2017/2459 replaces Article $24 \mathrm{~b}$ by adding that for supplies of services falling

11. For example if a service can be supplied via at least two different channels (a fixed landline or mobile networks) and the supplier cannot know and should not have known which one actually was used by the customer for receiving the service he should opt for the general presumption. 
under point (d), where the total value of such supplies, exclusive of VAT, provided by a taxable person from his business establishment or a fixed establishment located in a Member State ${ }^{12}$ does not exceed EUR 100,000, or the equivalent in national currency, ${ }^{13}$ in the current and the preceding calendar years, ${ }^{14}$ the presumption will be that the customer is established, has his permanent address or usually resides at the place identified as such by the supplier on the basis of one item of evidence provided by a person involved in the supply of the services other than the supplier or the customer, as listed in points (a) to (e) of Article 24f; see further below. (This simplification of the requirement to prove the customer's location is complementary to the amendments to be introduced in the special (Union and non-Union) schemes, see Section 2.2.3.9, and applies therefore from the same date, i.e. from 1 January 2019.)

Article 24f provides that the following shall, in particular, serve as evidence:

a. the billing address of the customer;

b. the Internet Protocol (IP) address of the device used by the customer or any method of geolocation;

c. bank details such as the place where the bank account used for payment is and the billing address of the customer held by that bank;

d. the Mobile Country Code (MCC) of the International Mobile Subscriber Identity (IMSI) stored on the Subscriber Identity Module (SIM) card used by the customer;

e. the location of the customer's fixed landline through which the service is supplied to him;

f. other commercially relevant information.

\subsubsection{The Place of Supply in the Member State of the Supplier Up to a Threshold of EUR 10,000}

The VAT Directive provides for special schemes for charging VAT for non-established taxable persons providing telecommunications, broadcasting and electronically supplied services (TBE services) to non-taxable persons (see Arts. 58 and 357-369k). Directive (EU) $2017 / 2455$ reduces the burden for micro-businesses established in a Member State occasionally supplying such services to other Member States of having to comply with VAT obligations in Member States other than their Member State of establishment. A Union-wide threshold is therefore introduced, up to which those supplies remain subject to VAT in their Member State ${ }^{15}$ of establishment. ${ }^{16}$

12. Note that the new rule applies for EU suppliers only

13. The corresponding value in national currency of the amount is to be calculated by applying the exchange rate published by the ECB.

14. Where, during a calendar year, this threshold has been exceeded, that paragraph does not apply as of that time and until such time as the mentioned conditions are fulfilled again.

15. Note that the new rule applies for EU suppliers only

16. Also, the requirement of having to comply with the invoicing requirements of all Member States to which supplies are made is very burdensome; see Section 2.1.3. From 1 January 2019, taxable persons not established in the Union but having a VAT registration in a Member State, for example because they carry out occasional transactions subject to VAT in that Member State, are permitted to use the special
With effect from 1 January 2019, paras. 2-6 are added to Article 58 of the VAT Directive so as to introduce a threshold of EUR 10,000 below which the place of supply of services that may be covered by the intra-Community special scheme for electronic services remains in the Member State of the supplier. This should, however, be optional for taxable persons so as to allow them to use the Mini One-Stop Shop (MOSS) anyhow, e.g. if during a calendar year their turnover is exceptionally below the threshold, this option covers, in any event, two calendar years. (As of 1 January 2021, Directive (EU) 2017/2455 replaces the above paragraphs by Article 59 c dealing with the threshold for taxable persons making supplies of goods covered by Article 33, point a - see Section 2.2.3.3 - and supplies of services covered by Art. 58; see Section 2.2.3.4).

\subsubsection{The Invoicing Rules of a Single Member State}

With effect from 1 January 2019, Article 219a of the VAT Directive is amended to provide that the invoicing rules of the Member State of identification apply. As a consequence, suppliers should respect the invoicing rules of a single Member State instead of, as is the case under the transitional rules, each Member State of destination to which supplies are made.

Article 219a is replaced by the following (changes in italics):

1. Invoicing shall be subject to the rules applying in the Member State in which the supply of goods or services is deemed to be made, in accordance with the provisions of Title $\mathrm{V}$.

2. By way of derogation from paragraph 1, invoicing shall be subject to the following rules:

a. the rules applying in the Member State in which the supplier has established his business or has a fixed establishment from which the supply is made or, in the absence of such place of establishment or fixed establishment, the Member State where the supplier has his permanent address or usually resides, where:

i. the supplier is not established in the Member State in which the supply of goods or services is deemed to be made, in accordance with the provisions of Title $\mathrm{V}$, or his establishment in that Member State does not intervene in the supply within the meaning of point (b) of Article 192a, and the person liable for the payment of the VAT is the person to whom the goods or services are supplied unless the customer issues the invoice (self-billing);

ii. the supply of goods or services is deemed not to be made within the Community, in accordance with the provisions of Title $\mathrm{V}$;

b. the rules applying in the Member State where the supplier making use of one of the special schemes referred to in Chapter 6 of Title XII is identified [i.e. the Union and non-Union schemes BT].

scheme for taxable persons not established within the Union; see Section 2.1.4. 
3. Paragraphs 1 and 2 of this Article shall apply without prejudice to Articles 244 to 248 .

Articles 244-248 referred to the above deal with storage of invoices (see also Art. 242a in Section 2.2.3.8).

\subsubsection{The Use of the Non-Union Scheme, Even If Othermise Required to be Identified for VAT Purposes}

Originally, based on Articles 358a-369 of the VAT Directive, taxable persons not established in the Union but having a VAT registration in a Member State, for example because they carry out occasional transactions subject to VAT in that Member State, could use neither the special scheme for taxable persons not established in the Union nor the special scheme for taxable persons established in the Union.

Based on Directive (EU) 2017/2455, with effect from 1 January 2019, in order to allow such taxable persons to use the non-Union scheme, the Directive deletes the words 'and who is not otherwise required to be identified for VAT purposes' from the definition of 'taxable person not established within the Community' in Article $358 \mathrm{a}$ of the VAT Directive ${ }^{17}$ and adapts Article 361(1)(e) of the VAT Directive accordingly. ${ }^{18}$

\subsection{Amendments to the VAT Directive with Effect from 1 January 2021}

\subsubsection{Extension to Supplies of Services Other Than TBE Services}

In order to avoid that taxable persons supplying services other than TBE services to non-taxable persons have to be identified for VAT purposes in each and every Member State where those services are subject to VAT, Member States should permit taxable persons supplying such services to make use of the IT system for registration and for declaration and payment of the VAT allowing them to declare and pay VAT on those services in a single Member State.

\subsubsection{Extension to Intra-EU Distance Sales of Goods} (B2C)

Furthermore, the special TBE scheme, supplies by taxable persons established within the Community but not in the Member State of consumption, is extended to intra-Community distance sales of goods - see the changes in the Union scheme in Section 2.2.3.9 - and a similar special scheme (the Import One-Stop Shop; IOSS) is introduced for distance sales of goods imported

17. Originally providing (our emphasis) '358a. 1. "Taxable person not established within the Community" means a taxable person who has not established his business in the territory of the Community and who has no fixed establishment there and who is not otherwise required to be identified for VAT purposes.'

18. Originally providing (our emphasis) '361. 1. The information which the taxable person not established within the Community must provide to the Member State of identification when he commences a taxable activity shall contain the following details: ... (e) a statement that the person is not identified for VAT purposes within the Community.' From 1 January 2019: '(e) a statement that the person has not established his business in the territory of the Community and has no fixed establishment there. from third territories or third countries; see Section 2.2.3.10.

\subsubsection{Other Changes}

With effect from 1 January 2021, Directive (EU) $2017 / 2455$ provides for definitions of distance sales of goods (see Section 2.2.3.1), makes electronic interfaces when facilitating distance sales of imported goods or intra-EU supplies deemed suppliers (see Section 2.2.3.2), reformulates Article 33 on distance sales (see Section 2.2.3.3), combines the threshold for telecommunications, broadcasting and electronically supplied services (TBE services) and intra-EU supplies of goods (see Section 2.2.3.4), defines the chargeable event and chargeability where an electronic interface is deemed supplier (see Section 2.2.3.5), introduces an exemption on importation (see Section 2.2.3.6), removes the obligation to issue an invoice for intra-EU distance sales when the Union scheme is used (see Section 2.2.3.7), deals with record-keeping obligations (see Section 2.2.3.8), deals with changes in the special schemes for taxable persons making supplies to non-taxable persons (see Section 2.2.3.9) and, finally, amends Directive 2009/132/EC (see Section 2.2.3.11).

\subsubsection{Definitions of Distance Sales of Goods}

With effect from 1 January 2021, in Article 14, a paragraph 4 is added, defining:

1. 'intra-Community distance sales of goods' as meaning supplies of goods dispatched or transported by or on behalf of the supplier, including where the supplier intervenes indirectly in the transport or dispatch of the goods, from a Member State other than that in which dispatch or transport of the goods to the customer ends, where the following conditions are met:

a. the supply of goods is carried out for a taxable person, or a non-taxable legal person, whose intraCommunity acquisitions of goods are not subject to VAT pursuant to Article 3(1) or for any other non-taxable person;

b. the goods supplied are neither new means of transport nor goods supplied after assembly or installation, with or without a trial run, by or on behalf of the supplier; and defining

2. 'distance sales of goods imported from third territories or third countries' as meaning supplies of goods dispatched or transported by or on behalf of the supplier, including where the supplier intervenes indirectly in the transport or dispatch of the goods, from a third territory or third country, to a customer in a Member State, other than that in which dispatch or transport of the goods to the customer ends where the following conditions are met:

a. the supply of goods is carried out for a taxable person, or a non-taxable legal person, whose intraCommunity acquisitions of goods are not subject to VAT pursuant to Article 3(1) or for any other non-taxable person;

b. the goods supplied are neither new means of transport nor goods supplied after assembly or installa- 
tion, with or without a trial run, by or on behalf of the supplier.

The definition of distance sales of goods imported from third territories or third countries is similar to the wording of Article 33(2), the inclusion where the supplier intervenes indirectly has been added. See also the place of supply of distance sales of goods imported from third territories or third countries, Section 2.2.3.3.

See further the exemption on importation in Section 2.2.3.6, the special import scheme in Section 2.2.3.10 and Article 369n dealing with the chargeable event and chargeability when the special import scheme is applied in Section 2.2.3.10. (The definition will be changed, inter alia, into intra-Union distance sales of goods; see further Section 4.2.2.)

\subsubsection{Electronic Interfaces When Facilitating}

Distance Sales of Imported Goods or Intra-EU Supplies

According to the preamble (point 7) of Directive (EU) 2017/2455, a major share of distance sales of goods, both supplied from one Member State to another and from third territories or third countries to the Community, are facilitated through the use of an electronic interface such as a marketplace, platform, portal or similar means, often resorting to fulfilment warehousing arrangements. While Member States may provide that a person other than the person liable for the payment of VAT is to be held jointly and severally liable for payment of VAT in such cases, see Article 205 of the VAT Directive, this has proved insufficient to ensure effective and efficient collection of VAT. To achieve that objective and reduce the administrative burden for vendors, tax administrations and consumers, it is, therefore, necessary to involve taxable persons who facilitate distance sales of goods through the use of such an electronic interface in the collection of VAT on those sales by providing that they are the persons who are deemed to make those sales. For distance sales of goods imported from third territories or third countries to the Community, this is restricted to sales of goods that are dispatched or transported in consignments of an intrinsic value not exceeding EUR 150, as of which a full customs declaration upon importation is required for customs purposes. The following Article 14a is added (presumably extending the application of the commission provision in Article 14(2)(b)), also applicable with effect from 1 January 2021:19

Where a taxable person facilitates, through the use of an electronic interface such as a marketplace, platform, portal or similar means, distance sales of goods imported from third territories or third countries in consignments of an intrinsic value not exceeding

19. It should be noted that Art. 14a is inserted into the VAT Directive, while this provision was not subject to an impact assessment by the Commission, since Art. 14a and recital 7 were not part of the initial legislative proposal. One may wonder whether this adopted provision violates the Commission's right of initiative (Art. 17 TEU).
EUR 150, that taxable person is deemed to have received and supplied those goods himself.

Where a taxable person facilitates, through the use of an electronic interface such as a marketplace, platform, portal or similar means, the supply of goods within the Community by a taxable person not established within the Community to a non-taxable person, the taxable person who facilitates the supply is deemed to have received and supplied those goods himself.

At this place we note that also Article 9a of Regulation (EU) No. 282/2011 introduced a similar presumption that for the application of Article 28 of the VAT Directive, where electronically supplied services are supplied through a telecommunications network, an interface or a portal such as a marketplace for applications, a taxable person taking part in that supply is presumed to be acting in his own name but on behalf of the provider of those services unless that provider is explicitly indicated as the supplier by that taxable person and that is reflected in the contractual arrangements between the parties. Furthermore, we note that the deeming provision of Article 14a does not apply in C2C supplies (e.g. eBay) and that the deeming provision does apply even to domestic sales but does apply irrespective of whether the interface is established in the EU or not.

See also the added Article 66a in Section 2.2.3.5 and Article 242a in Section 2.2.3.8.

On 11 December 2018, the Commission presented its proposals for a Directive amending the VAT Directive as regards provisions relating to distance sales of goods and certain domestic supplies of good, see Section 2.5 and for an implementing Regulation amending Implementing Regulation (EU) No 282/2011 as regards supplies of goods or services facilitated by electronic interfaces and the special schemes for taxable persons supplying services to non-taxable persons, making distance sales of goods and certain domestic supplies of goods, see Section 2.2.4. See also a proposal for a Council Regulation amending Regulation (EU) No 904/2010 as regards measures to strengthen administrative cooperation in order to combat VAT fraud. The latter proposal is part of the package of legislation on the mandatory transmission and exchange of VAT-relevant payment information. The context of the package as a whole is set out comprehensively in the explanatory memorandum of the proposal for a Council Directive amending the VAT Directive as regards introducing certain requirements for payment service providers.

\subsubsection{Reformulation of Article 33 on Distance Sales;} Removal of Thresholds

With effect from 1 January 2021, Article 33 will provide that

a. the place of supply of intra-Community distance sales of goods shall be deemed to be the place where the 
goods are located at the time when dispatch or transport of the goods to the customer ends ${ }^{20}$ and

b. the place of supply of distance sales of goods imported from third territories or third countries into a Member State other than that in which dispatch or transport of the goods to the customer ends is deemed to be the place where the goods are located at the time when dispatch or transport of the goods to the customer ends, while

c. the place of supply of distance sales of goods imported from third territories or third countries into the Member State in which dispatch or transport of the goods to the customer ends shall be deemed to be in that Member State, provided that VAT on those goods is to be declared under the IOSS (the special scheme for goods imported from third territories or third countries); see Section 2.2.3.10.

Article 33(2) of the VAT Directive as applicable until 2021 provides that where goods sold 'on distance' are imported into a Member State other than the Member State in which the transport to the customer ends, a supply of goods is deemed to take place in the latter Member State. According to the explanatory memorandum to the proposal for the Directive, to allow the use of the special scheme also in situations where the Member State where the customer is located and the Member State of importation are the same, a second subparagraph is added in Article 33 creating a taxable event in that Member State where the special scheme is used.

It should be noted that the existing intra-Community distance sales thresholds are removed (deleting Art. 34 and the reference to Art. 34 in Art. $35^{21}$ ). Furthermore, a threshold for taxable persons making supplies of goods covered by Article 33(1) and supplies of services covered by Article 58 is introduced, see Article 59c in Section 2.2.3.4.

\subsubsection{Combination of the Threshold of EUR 10,000 for TBE Services and Intra-EU Supplies of Goods}

As mentioned in Section 2.1.2, with effect from 1 January 2019, paragraphs 2-6 are added to Article 58 of the VAT Directive so as to introduce a threshold of EUR 10,000 below which the place of supply of services that may be covered by the intra-Community special scheme for electronic services remains in the Member State of the supplier.

As of 1 January 2021, Directive (EU) 2017/2455 replaces the above paragraphs by Article 59c dealing with the threshold for taxable persons making supplies of goods covered by Article 33, point (a) (see Section 2.2.3.3) and

20. See also Art. 59c in Section 2.2.3.4 not applying Art. 33(a) under certain conditions.

21. Art. 35 provides that Arts. 33 and 34 shall not apply to supplies of second-hand goods, works of art, collectors' items or antiques, as defined in points (1) to (4) of Art. 311(1), nor to supplies of second-hand means of transport, as defined in Art. 327(3), subject to VAT in accordance with the relevant special arrangements. supplies of TBE services covered by Article 58 providing:

Point (a) of Article 33 and Article 58 do not apply, where the following conditions are met:

a. the supplier is established or, in the absence of an establishment, has his permanent address or usually resides only in one Member State;

b. services are supplied to non-taxable persons who are established, have their permanent address or usually reside in any Member State other than the Member State referred to in point (a) or goods are dispatched or transported to a Member State other than the Member State referred to in the first indent; and

c. the total value, exclusive of VAT, of the supplies referred to in point (b) does not in the current calendar year exceed EUR 10,000, or the equivalent in national currency, nor did it do so in the course of the preceding calendar year.

As mentioned in Section 2.2.3.3 the existing intra-Community distance sales thresholds are removed (deleting Art. 34 and the reference to Art. 34 in Art. 35).

\subsubsection{Chargeable Event and Chargeability Where an} Electronic Interface Is Deemed Supplier

With effect from 1 January 2021, Article 66a is inserted providing that by way of derogation from Articles 63 (when goods or services are supplied), 64 (successive statements of account) and 65 (payment on account) in respect of supplies of goods for which VAT is payable by the person facilitating the supply pursuant to Article 14a (see Section 2.2.3.2), the chargeable event occurs and VAT becomes chargeable at the time when the payment has been accepted.

See also Art. 369n in Section 2.2.3.10, dealing with the chargeable event and chargeability when the special import scheme is applied.

\subsubsection{Exemption on Importation Threshold of EUR} 150

According to the preamble (point 10) of Directive (EU) $2017 / 2455$, the scope of the special scheme for distance sales of goods imported from third territories or third countries should be restricted to sales of goods of an intrinsic value not exceeding EUR 150 (see also Section 2.2.3.1) that are dispatched directly from a third territory or third country to a customer in the Community, as of which a full customs declaration is required for customs purposes upon importation. Goods subject to excise duty are excluded from its scope as excise duty is part of the taxable amount for VAT upon importation. In order to avoid double taxation, an exemption from VAT upon importation of the goods declared under that special scheme is introduced.

This exemption is inserted as paragraph (ca) of Article 143(1) of the VAT Directive. To allow customs to identify these consignments upon importation a valid VAT identification number proving that VAT is declared under the special scheme should be provided to customs at the latest upon lodging of the import declaration. 


\subsubsection{Removal of the Obligation to Issue an Invoice for Intra-EU Distance Sales When the Special Scheme on Importation Is Used}

According to the preamble (point 9) of Directive (EU) $2017 / 2455$ to reduce the burden for businesses making use of the special scheme for intra-Community distance sales of goods, the obligation to issue an invoice for such sales is to be removed. To provide legal certainty to such businesses, the definition of those supplies of goods should clearly state that it applies also where the goods are transported or dispatched on behalf of the supplier, including where the supplier intervenes indirectly in the transport or dispatch of the goods.

According to Article 220(2), as applicable from 2013, an invoice must be issued in respect of i) supplies of goods or services to another taxable person or to a non-taxable legal person; ii) supplies of goods subject to the distance selling rules of Article 33, except where a taxable person is making use of the special scheme in Chapter 3 of Chapter 6 of Title XII; iii) exempt intra-Community supplies of goods referred to in Article 138; iv) any payment on account made before one of the supplies of goods referred to in points (1) and (2) was carried out; v) any payment on account by another taxable person or non-taxable legal person before the provision of services was completed.

With effect from 1 January 2021, based on Directive (EU) $2017 / 2455$, the following is added to point (2): 'except where a taxable person is making use of the special scheme in Section 3 of Chapter 6 of Title XII', i.e. the special scheme for distance sales of goods imported from third territories or third countries; see Section 2.2.3.10.

\subsubsection{Record-Keeping Obligations}

According to the preamble (point 8) of Directive (EU) $2017 / 2455$, the keeping of records for a period of at least 10 years in respect of supplies by taxable persons facilitated by an electronic interface such as a marketplace, platform, portal or similar means is necessary to assist Member States to verify that VAT has been accounted for correctly on those supplies. The period of 10 years is consistent with existing record-keeping provisions. Where the records consist of personal data, they should comply with Union law on data protection.

With effect from 1 January 2021, Article 242a is added to the VAT Directive providing that where a taxable person facilitates, through the use of an electronic interface such as a marketplace, platform, portal or similar means, the supply of goods or services ${ }^{22}$ to a non-taxable person within the Community in accordance with the provisions of Title $\mathrm{V}$, i.e. the place of taxable transaction (see especially Section 2.2.3.2 above), the taxable person who facilitates the supply is obliged to keep records of that supply. Those records must be sufficiently detailed

22. We note that services are added while the new Art. 14a only refers to goods. Presumably, reference is made to electronically supplied services as referred to in Art. 9a of the implementing Regulation. However, Art. 9 a refers to a taxable person taking part in that supply, rather than merely facilitating. to enable the tax authorities of the Member States where those supplies are taxable to verify that VAT has been accounted for correctly. Those records must be made available electronically on request to the Member States concerned and must be kept for a period of 10 years from the end of the year during which the transaction was carried out.

\subsubsection{Changes in the Special Schemes; Taxable} Persons Supplying Services to Non-taxable Persons

According to the preamble (point 5) of Directive (EU) 2017/2455:

In order to avoid that taxable persons supplying services other than TBE services to non-taxable persons have to be identified for VAT purposes in each and every Member State where those services are subject to VAT, Member States should permit taxable persons supplying such services to make use of the IT system for registration and for declaration and payment of the VAT allowing them to declare and pay VAT on those services in a single Member State.

Although the main rule of the place of supply of services to non-taxable persons is where the supplier has established his business (see Art. 45 of the VAT Directive), there are many exceptions, see Articles 46-57 - other than TBE services - and 59a of the VAT Directive, which would require taxable persons supplying those services to non-taxable persons to be identified for VAT purposes in each and every Member State where those services are subject to VAT.

Furthermore, the special TBE scheme, supplies by taxable persons established within the Community but not in the Member State of consumption, is extended to intra-Community distance sales of goods, and a similar special scheme is introduced for distance sales of goods imported from third territories or third countries (see also Sections 2.2.1 and 2.2.3.3).

Therefore, the title of Chapter 6 'Special schemes for non-established taxable persons supplying telecommunications services, broadcasting services or electronic services to non-taxable persons' is changed from 1 January 2021 into 'Special schemes for taxable persons supplying services to non-taxable persons or making distance sales of goods'. Also, the title of the non-Union scheme 'Chapter 2 Special scheme for telecommunications, broadcasting or electronic services supplied by taxable persons not established within the Community' is changed from 1 January 2021 into 'Chapter 2 Special scheme for services supplied by taxable persons not established within the Community', and the title of the Union scheme 'Chapter 3 Special scheme for telecommunications, broadcasting or electronic services supplied by taxable persons established within the Community but not in the Member State of consumption' is changed from 1 January 2021 into 'Chapter 3 Special scheme for intra-Community distance sales of goods and for services supplied by taxable persons established 
within the Community but not in the Member State of consumption'.

Furthermore, with regard to the general provisions in Article 358, the definitions of 'telecommunications services', 'broadcasting services', 'electronic services', 'electronically supplied services' (all of those definitions can already be found in Article 58 of the VAT Directive) and 'Member State of consumption' are deleted (for the latter see Article 358a under the non-Union scheme and Article 369a under the Union scheme). What remains is the definition of 'VAT return', meaning the statement containing the information necessary to establish the amount of VAT due in each Member State.

The detailed changes in the non-Union scheme and in the Union scheme are not discussed here.

\subsubsection{The IOSS (Special Import Scheme} Threshold of EUR 150)

Directive (EU) 2017/2455 amending the VAT Directive (and Directive 2009/132/EC, see Section 2.2.3.11) as regards certain value added tax obligations for supplies of services and distance sales of goods introduces a special 'import' scheme for distance sales of goods imported from third countries or third territories with effect from 1 January 2021.

In short: for consignments of a value up till EUR 150 the IOSS can be used to declare and pay the VAT.

- The vendor (directly or via an intermediary) registers for the IOSS in a Member State (the Member State of Identification)

- The vendor charges the VAT to the customer at the time of the supply defined as the time when the payment is accepted

- He declares and pays the VAT in the Member State of Identification on the basis of a monthly One-Stop Shop return; the Member State of Identification transfers the VAT to all Member States of consumption

- These consignments are VAT exempt upon importation (the IOSS EU VAT number must be communicated at the latest upon lodging of the import declaration).

Each Member State must compile a monthly listing including the total value of imports under the IOSS, per IOSS VAT number.

Article 3691 lays down the definitions applying to this special scheme. The definition of 'distance sales of goods imported from third countries' defines the scope of this special scheme, which covers sales of goods in consignments of an intrinsic value (i.e. the value of the goods alone, excluding insurance and freight) not exceeding EUR 150, the place of supply of which is governed by Article 33(2) of the VAT Directive. It currently provides that where goods sold 'on distance' are imported into a Member State other than the Member State in which the transport to the customer ends, a supply of goods is deemed to take place in the latter Member State. To allow the use of the special scheme also in situations where the Member State where the customer is located and the Member State of importation are the same, a second subparagraph is added in Article 33, creating a taxable event in that Member State where the special scheme is used; see also Section 2.2.3.3.

A definition of what is an 'intermediary' is necessary, as it should be possible for vendors not established within the Community to designate a person established within the Community to fulfil their VAT obligations under this special scheme in their name and on their behalf. Which Member State can be the 'Member State of identification' depends on whether or not the vendor is established or has a fixed establishment in the Community and whether or not an intermediary has been designated by the vendor. Finally, the 'Member State of consumption' refers to the Member State where the transport to the customer ends.

Article $369 \mathrm{~m}$ provides who is eligible to use the special import scheme. According to the Directive, a vendor not established in the Community should designate an intermediary except ${ }^{23}$ if he is established in a country with which the EU has concluded an agreement on mutual assistance. The list of countries concerned should be established subsequently in a Commission Implementing Regulation. ${ }^{24}$

Article 369 n provides that VAT shall become chargeable at the time when the payment has been accepted. This provision is needed to determine which supplies should be included in the periodic VAT return.

Articles $3690-369 \mathrm{x}$ replicate the provisions of the two other special (Union and non-Union) schemes concerning identification, VAT returns, VAT payments, refunds and record keeping. Note that Article 369s contains a provision specific to the import scheme stipulating that Member States should not impose any further declarative obligations on top of the periodic VAT return.

23. According to the preamble to Directive (EU) 2017/2455, point (12), a taxable person making use of the special scheme for distance sales of goods imported from third territories or third countries should be allowed to appoint an intermediary established in the Community as the person liable for payment of the VAT and to fulfil the obligations laid down in that special scheme in his name and on his behalf. Point (13) mentions that in order to protect Member States' tax revenue, a taxable person not established in the Community making use of this special scheme should be obliged to designate an intermediary. However, that obligation should not apply if he is established in a country with which the Union has concluded an agreement on mutual assistance; see also the next footnote.

24. According to the preamble to Directive (EU) 2017/2455, point (14), in order to ensure uniform conditions for the implementation of this Directive concerning the establishment of the list of third countries with which the Union has concluded an agreement on mutual assistance similar in scope to Council Directive 2010/24/EU and Council Regulation (EU) No 904/2010, implementing powers should be conferred on the Commission. Those powers should be exercised in accordance with Regulation (EU) No 182/2011 of the European Parliament and of the Council. Since the establishment of the list of third countries is directly linked with the administrative cooperation in the field of value added tax, it is appropriate that the Commission be assisted by the Standing Committee on Administrative Cooperation set up by Art. 58 of Regulation (EU) No 904/2010. 
Where VAT is declared under the special import scheme, no VAT should be payable anymore upon importation of the goods. It is therefore necessary to provide for an exemption for such imports. This exemption is inserted in Article 143(1) of the VAT Directive as paragraph (ca); see Section 2.2.3.6. To allow customs to identify these consignments upon importation, a valid VAT identification number proving that VAT is declared under the special scheme should be provided to customs at the latest upon lodging of the import declaration.

\subsection{Special Arrangements for Declaration and Pay- ment of Import VAT and Exchange Values}

The preamble (point 15) of Directive (EU) 2017/2455 recites that following the explosive growth of electronic commerce and the resulting increase in the number of small consignments of an intrinsic value not exceeding EUR 150 imported in the Community, Member States should systematically permit the use of special arrangements for declaration and payment of import VAT. Those arrangements can be applied where the IOSS is not used. Where the Member State of importation does not provide for the systematic application of reduced VAT rates under this special arrangement, the final customer should be able to opt for the standard import procedure in order to avail himself of a potential reduced VAT rate.

Simplification measures are introduced for goods in consignments of a value for which VAT is not accounted for via the special import scheme (Arts. $369 \mathrm{y}-369 \mathrm{zb})$.

Where, for the importation of goods, except products subject to excise duties, in consignments of an intrinsic value not exceeding EUR 150, the special import scheme in Section 2.2.3.9 above is not used, the Member State of importation must permit the person presenting the goods to customs on behalf of the person for whom the goods are destined within the territory of the Community (typically the postal operators or express couriers) to make use of special arrangements for declaration and payment of import VAT in respect of goods for which the dispatch or transport ends in that Member State (Art. 369y).

For the purpose of this special arrangement, the following applies:

a. the person for whom the goods are destined is liable for the payment of the VAT;

b. the person presenting the goods to customs within the territory of the Community is to collect the VAT from the person for whom the goods are destined and effect the payment of such VAT (Art. 369z). ${ }^{25}$

By way of derogation from Article 94(2), which provides that the rate applicable to the importation of goods shall be that applied to the supply of like goods within the territory of the Member State, Member States may provide that the standard rate of VAT applicable in the Member State of importation is applicable when using this special arrangement (Art. 369za).

Member States must allow that the VAT collected under this special arrangement be reported electronically in a monthly declaration. The declaration shall show the total VAT collected during the relevant calendar month. The Member States must require that the VAT collected is payable by the end of the month following the importation. The persons making use of this special arrangement must keep records of the transactions covered by this special arrangement for a period of time to be determined by the Member State of importation. Those records must be sufficiently detailed to enable the tax or customs authorities of the Member State of importation to verify that the VAT declared is correct and be made available electronically on request to the Member State of importation (Art. 369zb).

In short, the special arrangements for declaration and payment of import VAT are:

- Member States must allow the use of existing simplified customs procedures for the monthly global declaration and payment of import VAT to customs;

- Member States may allow the systematic use of the standard VAT rate;

- The declarant must only pay VAT that has effectively been collected from the consignee;

- The declarant must take appropriate measures to ensure correct VAT payment by the consignee;

- The declarant must comply with record-keeping obligations.

Article $369 \mathrm{zc}$ deals with the exchange value in national currency of the euro to be taken into consideration for the amount mentioned in Articles 3691 and 369y (the intrinsic value not exceeding EUR 150) to be fixed once a year.

\subsubsection{Amendment of Directive 2009/132/EC}

Directive 2009/132/EC determines the scope of Article 143(b) and (c) of the VAT Directive as regards exemption from value added tax on the final importation of certain goods. Articles 23 and 24 of that Directive provide for an exemption for imported goods of negligible value not exceeding a total value of EUR 10 up to EUR 22 (amount to be decided by each Member State). ${ }^{26}$

The preamble (point 11) of Directive (EU) 2017/2455 recites that in order to avoid distortion of competition between suppliers inside and outside the Community and to avoid losses of tax revenue, it is necessary to remove the exemption for imports of goods in small consignments of negligible value provided for in Directive 2009/132/EC.

As the use of the special import scheme (and thus of the MOSS) will allow for VAT to be declared and paid on imported goods ordered online and thus will drastically

26. Estimated VAT forgone by the low value consignments relief (LVCR) is approximately 1 billion Euros per year, in addition to a loss of 5 to 7 billion by undervalued and misdescribed imports. 
simplify VAT collection, there is no need to maintain this VAT exemption. Directive (EU) 2017/2455 therefore removes this exemption as from 1 January 2021, which is the date of entry into force of the import scheme; see Section 2.2.10 above. Furthermore, simplification measures are introduced for goods in consignments of a value for which VAT is not accounted for via the import scheme.

\subsubsection{Amendments of Regulation (EU) No $904 / 2010$}

On 5 December 2017, the Council adopted Regulation (EU) No 2017/2454 amending Regulation (EU) No $904 / 2010$ on administrative cooperation and combating fraud in the field of value added tax. The extension from 1 January 2021 of the special schemes to distance sales of goods (see Section 2.1) and services other than TBE services (see Section 2.2.3.9) requires extending the scope of the rules of the Regulation, inter alia, concerning the provision of information between the Member State of identification and the Member States of consumption with effect from 1 January 2021.

\subsubsection{Proposal for a Directive Amending the VAT Directive as Regards Provisions Relating to Distance Sales $^{27}$}

On 11 December 2018, the Commission presented its proposal for a Directive amending the VAT Directive as regards provisions relating to distance sales of goods and certain domestic supplies of goods. ${ }^{28}$

In October 2017, the Commission had already committed to address the administrative capacity of tax authorities to fight electronic commerce (hereinafter 'e-commerce') VAT fraud by improving cooperation with third parties. In the statement included in the minutes for the adoption of Council Directive (EU) 2017/2455 (the VAT e-commerce Directive) in December 2017, the Council stressed the need to improve anti-fraud tools. In particular, the VAT ecommerce Directive introduced new VAT obligations for online marketplaces and new simplifications to help businesses comply with VAT obligations for supplies of services, distance sales of goods and imports, including electronic VAT registration and VAT payment through the One Stop Shop (registration in one single Member States instead of in all the Member States of consumption). These measures will strengthen VAT compliance by simplifying the VAT system, but tax authorities still need to be able to detect and control fraudulent businesses. At present, this is a challenge for tax authorities. The European Court of Auditors has remarked that the VAT legislation on e-commerce essentially relies on the willingness of businesses to voluntarily register and pay the due VAT. There are nevertheless limits to how Member States can use the current legal framework for adminis- trative cooperation. If the abovementioned compliance simplifications are not accompanied by anti-fraud measures, fraudsters will have little incentive to change their attitude and start complying with VAT obligations. Thus, the success of compliance measures in e-commerce also depends on the effectiveness of anti-fraud measures, which must be developed in parallel.

The proposal seeks to solve the problem of e-commerce VAT fraud by strengthening the cooperation between tax authorities and payment service providers. In recent years, more than $90 \%$ of online purchases by European customers were made through credit transfers, direct debits and card payments, i.e. through an intermediary involved in the transaction (a payment service provider), and this is a trend that will continue in the future. Third parties that hold payment information can therefore give a complete picture of online purchases to tax authorities to help them properly carry out their task of monitoring compliance with VAT obligations on e-commerce supplies of goods and services. The experience of the Member States that already cooperate with payment service providers at national level has shown that cooperation with payment service providers produces tangible results in fighting e-commerce VAT fraud. Some third countries also use payment information as a tool for detecting non-compliant traders in combination with simplified collection regimes for cross-border B2C supplies of good similar to the EU system. ${ }^{29}$

\subsubsection{Reasons for and Objectives of the Proposal}

On 5 December 2017, the Council adopted Council Directive (EU) 2017/2455 ("the VAT e-commerce Directive", discussed in Sections 2.1-2.2 above) amending the VAT Directive which, inter alia:

- Extends the scope of the special schemes for nonestablished taxable persons supplying telecommunications, broadcasting or electronic services to nontaxable persons, as defined in Articles 358 to $369 \mathrm{k}$ of the VAT Directive (the so-called "mini One Stop Shop") to all types of services as well as to intraCommunity distance sales of goods and distance sales of goods imported from third territories or third countries, turning the mini One Stop Shop into a One Stop Shop. The mini One Stop Shop allows suppliers of such services to use a web portal in the Member State in which they are identified to account for the VAT due in other Member States;

- Introduces special provisions applicable to taxable persons who facilitate certain supplies to non-taxable persons made by other taxable persons through the use of an electronic interface such as a marketplace, platform, portal or similar means.

The objective of the proposal for a Directive amending the VAT Directive as regards provisions relating to dis-
27. The proposal has meanwhile been adopted by Council Directive (EU) 2019/1995 of 21 November 2019 amending Directive 2006/112/EC as regards provisions relating to distance sales of goods and certain domestic supplies of goods, OJ L 310, 2.12.2019, pp. 1-5.

28. $\operatorname{COM}(2018) 819$ final.
29. See also a proposal for a council regulation amending Regulation (EU) No 904/2010 as regards measures to strengthen administrative cooperation in order to combat VAT fraud. The proposal is part of the package of legislation on the mandatory transmission and exchange or VAT-relevant payment information. See further chapter 9.5. 
tance sales is to lay down additional rules needed to support these amendments to the VAT Directive which apply from 1 January 2021, insofar as such support cannot be attained through implementing measures laid down in Council implementing Regulation (EU) No 282/20113 ("the VAT implementing Regulation"). This concerns, in particular, the provisions relating to electronic interfaces facilitating supplies of goods to non-taxable persons in the EU by taxable persons not established in the EU and the special arrangements for declaration and payment of import VAT where the One Stop Shop for distance sales of goods imported from third territories or third countries is not used.

\subsubsection{Detailed Explanation of the Specific Provisions of the Proposal}

Article $14 \mathrm{a}$ inserted in the VAT Directive by the VAT e-commerce Directive, see Section 2.2.3.2, provides that where a taxable person facilitates, through the use of an electronic interface such as a marketplace, platform or portal either distance sales of goods imported from third territories or third countries in consignments of an intrinsic value not exceeding EUR 150 (Art. 14a(1)) or the supply of goods within the Community by a taxable person not established there to a non-taxable person (Art. 14a(2)), the taxable person who facilitates the supply shall be deemed to have received and supplied the goods himself.

This effectively splits a business to consumer supply (B2C supply) from the supplier selling goods through the use of the electronic interface to the customer into two supplies: a supply from that supplier to the electronic interface (B2B supply) and a supply from the electronic interface to the customer (B2C supply). It is therefore necessary to determine to which supply the dispatch or transport of the goods should be ascribed to properly determine their place of supply. Article 1, point (1) of the proposal provides that the dispatch or transport should be ascribed to the supply from the electronic interface to the customer, as also indicated in the statement included in the Council minutes upon the adoption of the VAT e-commerce Directive.

The straightforward application of Article $14 \mathrm{a}(2)$ would create additional administrative burdens for the companies concerned as well as the risk of VAT revenue losses resulting from the payment of $\mathrm{VAT}$ by the electronic interface to the supplier selling goods through the use of the electronic interface. The following amendments proposed address these issues:

- The B2B supply from the supplier selling goods through the use of the electronic interface to the electronic interface is exempt (Art. 1, point (2) of the proposal) with a right for that supplier to deduct the input VAT he paid himself in respect of the purchase or import of the goods supplied (Art. 1, point (3) of the proposal);

- According to Article $369 \mathrm{~b}$ of the VAT Directive as amended by the VAT e-commerce Directive, the One Stop Shop can only be used to declare and pay VAT on intra-Community distance sales of goods and not for a domestic supply of goods. A suppliers selling goods through the use of an electronic interface may hold a stock of goods in different Member States from which they make domestic supplies, electronic interfaces deemed to have supplied those goods themselves would be obliged to register for VAT in all these Member States to account for VAT on these domestic supplies. This would remove the simplification of the One Stop Shop for electronic interfaces and thus result in additional obligations for them. It is therefore proposed to allow electronic interfaces to use the One Stop Shop also for domestic supplies to customers when they are deemed to supply the goods themselves under Article $14 a(2)$ of the VAT Directive. This requires the following changes to Chapter 6 of Title XII of the VAT Directive:

- Amend the heading of the Chapter and of its Section 3 (Art. 1, points (5) and (6) of the proposal);

- Amend the definition of the Member State of consumption (Art. 1, point (7)(a) of the proposal);

- Extend the scope of the special scheme (Art. 1, point (8) of the proposal);

- Amend the provision on the exclusion of a taxable person form the special scheme (Art. 1, point (9) of the proposal);

- Allow the declaration of these domestic supplies in the One Stop Shop VAT return (Art. 1, points (10) and (11) of the proposal).

Finally, a last amendment is proposed in the special arrangements for declaration and payment of import VAT where the One Stop Shop is not used to declare VAT on distance sale of goods imported from third territories or third countries. According to Articles $369 y$ to $369 \mathrm{zb}$ as inserted in the VAT Directive by the VAT e-commerce Directive global payment of import VAT must be made to customs by the end of the month following that of importation. This payment deadline is however not aligned to the deadline laid down for global payment of the customs debt in Article 111 of the Union Custom Code, providing for deferred payment until the middle of the month following the month of importation. With this proposal, the deadline for deferred payment under these special arrangements is aligned with that provided for in the Union Customs Code (Art. 1, point (12) of the proposal).

Article 2 provides that the measures shall apply from 1 January 2021, which is the date of application of the relevant provisions of the e-commerce Directive. 


\subsubsection{Proposal for an Implementing Regulation as Regards Electronic Interfaces and the Special Schemes for Taxable Persons Supplying Services ${ }^{30}$}

On 11 December 2018, the Commission presented its proposal for an implementing Regulation amending implementing Regulation (EU) No 282/2011 a regards supplies of goods or services facilitated by electronic interface and the special schemes for taxable persons supplying services to non-taxable persons, making distance sales of goods and certain domestic supplies of goods. ${ }^{31}$

\subsubsection{Reasons for and Objective of the Proposal}

Article 397 of the VAT Directive provides that "the Council, acting unanimously on a proposal from the Commission, shall adopt the measures necessary to implement this Directive".

On that basis, the VAT implementing Regulation provides binding rules on the application of certain provisions of the VAT Directive. More in particular, Section 2 of Chapter XI of this Regulation lays down detailed provisions for the application of the special schemes for non-established taxable persons supplying telecommunications broadcasting or electronic services to non-taxable persons, as defined in Article 358 to $369 \mathrm{k}$ of the VAT Directive (the so-called "mini One Stop Shop"). The mini One Stop Shop allows suppliers of such services to use a web portal in the Member State in which they are identified to account for the VAT due in other Member States.

On 5 December 2017, the Council adopted Directive (EU) 2017/2455 ("the VAT e-commerce Directive") amending the VAT Directive which inter alia:

- Extends the scope of the mini One Stop Shop to all types of services as well as to intra-Community distance sales of goods and distance sales of goods imported from third territories or third countries, see Section 2.2.3.9, turning the mini One Stop Shop into a One Stop Shop;

- Introduces special provisions applicable to taxable persons who facilitate certain supplies made by other taxable persons through the use of an electronic interface such as a marketplace, platform, portal or similar means, see Section 2.2.3.2.

The objective of this proposal for an implementing Regulation as regards electronic interfaces and the special schemes for taxable persons supplying services is to lay down detailed implementation rules needed to support

30. The proposal has meanwhile been adopted by Council Implementing Regulation (EU) 2019/2026 of 21 November 2019 amending Implementing Regulation (EU) No 282/2011 as regards supplies of goods or services facilitated by electronic interfaces and the special schemes for taxable persons supplying services to non-taxable persons, making distance sales of goods and certain domestic supplies of goods, OJ L 313, 4.12.2019, pp. 14-27. See also Commission Implementing Regulation (EU) 2020/194 of 12 February 2020 laying down detailed rules for the application of Council Regulation (EU) No 904/2010 as regards the special schemes for taxable persons supplying services to non-taxable persons, making distance sales of goods and certain domestic supplies of goods, OJ L 40, 13 February 2020, pp. 114-124.

31. $\operatorname{COM}(2018) 821$ final. these amendments to the VAT Directive which apply from 1 January 2021. This is achieved through an amendment to the VAT implementing Regulation.

\subsubsection{Detailed Explanation of the Specific Provisions of the Proposal}

\subsection{Indirect Intervention of the Supplier in the Dis-} patch or Transport

Article 14(4) of the VAT Directive as amended by the VAT e-commerce Directive, see Section 2.2.1, defines 'intra-Community distance sales of goods' and 'distance sales of goods imported from third territories or third countries'. These definitions also cover supplies of goods where the supplier intervenes indirectly in their dispatch or transport to the customer. To ensure the correct and uniform application of these definitions, it is necessary to define the meaning of 'indirectly' ${ }^{32}$ So far, this notion has only been clarified in guidelines of the VAT Committee. The proposal inserts the text of these guidelines in the VAT implementing Regulation to enhance legal certainty for both economic operators and tax administrations (Art. 1, point (l)(b) of the proposal, adding a new Art. 5a to the Regulation).

\subsection{Provisions Relating to Electronic Interfaces}

Articles 14a and 242a of the VAT Directive as amended by the VAT e-commerce Directive, see Sections 2.2.3.2 and 2.2.3.8, introduce specific provisions for electronic interfaces such as a marketplace, platform or portal facilitating certain supplies of goods or services made by other taxable persons. In the statements included in the Council minutes when adopting the VAT e-commerce Directive, the Council invited the Commission to propose the necessary implementation rules for the application of these provisions, considering the following elements:

- Definition of the situation in which a taxable person is considered to facilitate sales of goods or services through the use of an electronic interface (this is proposed in Art. 1, point (l)(b) of the proposal, adding a new Art. $5 b$ to the Regulation and point (4) of the proposal, adding a new Art. 54b to the Regulation);

- Specific provisions on the conditions for determining when the payment is accepted to determine in which taxable period supplies by taxable persons facilitating supplies of goods in the Community through an electronic interface or by any taxable person making use of the special scheme for distance sale of goods from third territories or third countries should be declared (this is specified by Art. 1, point (3) of the proposal, adding a new Chapter Va and Article 4la to the Regulation and point (5) of the proposal, adding a new Article $61 \mathrm{~b}$ to the Regulation);

- The type of information to be kept in the records of taxable persons facilitating supplies of goods and services in the Community through the use of an elec-

32. This has also been recognised in point 3 of the preamble of Counci Implementing Regulation (EU) 2019/2026. 
tronic interface. Account should be taken of what information is available to such taxable persons, is relevant to tax administrations and is proportionate to the purpose of the provision, as well as of the need to comply with the General Data Protection Regulation (EU) 2016/679 (see Art. 1, points (4) of the proposal, adding a new Section la and Art. 54c to the Regulation).

Further to the discussions with Member States' authorities and businesses, Article 1, point (l)(b) of the proposal inserts a new Article $5 \mathrm{c}$ in the VAT implementing Regulation specifying that:

- When an electronic interface is deemed to have received and supplied goods itself, it shall not be held liable for the payment of any amount of VAT in excess of the VAT which it declared and paid on sales made through the electronic interface. Such a provision is required in order to allow Member States to release electronic interfaces from additional VAT payments where the electronic interface depend, on information provided by the supplier selling goods through the electronic interface and can prove that it acted in good faith;

- Any supplier selling good through the interface shall be presumed to be a taxable person and his customer to be a non-taxable person. This presumption releases the interface from the burden of having to prove the status of the seller and customer.

\subsection{Provisions Relating to the Extension of the Scope} of the One Stop Shop

The provisions relating to the extension of the scope of the One Stop Shop (Art. 1, point (5) of the proposal) replace Section 2 of Chapter XI of the VAT implementing Regulation).

Most of these provisions update Section 2 of Chapter XI of the VAT implementing Regulation, laying down implementing provisions required for the proper functioning of the mini One Stop Shop, following the extension of its scope.

In addition, a number of changes are proposed which go beyond the mere alignment of these provisions to the extension of the scope of the mini One Stop Shop. These changes relate to the following issues:

- Article 369q of the VAT Directive as amended by the VAT e-commerce Directive provides that the Member State of identification shall allocate an identification number to an intermediary acting in the name and on behalf of a taxable person using the One Stop Shop for distance sales of goods imported from third territories or third countries. A second paragraph is added to Article 57e of the VAT implementing Regulation clarifying that this identification number is an authorisation enabling him to act as intermediary and cannot be used by the intermediary to declare VAT on taxable transactions.

- Article $57 \mathrm{~g}$ of the VAT implementing Regulation provides that where a taxable person voluntarily ceases using the mini One Stop Shop regardless of whether he continues to supply goods or services which can be eligible for its use, he shall be excluded from the mini One Stop Shop in any Member State for two calendar quarters. This provision is removed as it is not considered useful by Member States and may create additional burdens for the taxable persons concerned.

The VAT e-commerce Directive allows making corrections to previous One Stop Shop VAT returns, within three years, in a subsequent return instead of having to re-submit the return of the tax period to which the corrections relate, as is the case in the mini One Stop Shop. The VAT e-commerce Directive does however not specify how corrections to returns relating to tax periods preceding 1 January 2021 have to be made as of 2021. To limit the TT impact of the changeover from one system to another, it is preferable to keep in place the current system for making corrections to mini One Stop Shop VAT returns relating to the periods from the fourth quarter of 2017 to the fourth quarter of 2020. The proposal amends Article 61 of the VAT implementing Regulation accordingly.

Under the One Stop Shop, corrections to previous VAT returns will have to be submitted in a subsequent return. Once the final VAT return has been submitted, it will no longer be possible for a taxable person excluded from the One Stop Shop pursuant to Article 61a of the VAT implementing Regulation to submit subsequent VAT returns. As a consequence, the proposal provides that any corrections to the final return and previous returns arising after the submission of the final return shall be discharged directly with the tax authorities of the Member State of consumption concerned.

The records to be kept by a taxable person using the mini One Stop Shop currently include the name of the customer, where known to the taxable person. As this information must only be kept if available, is not needed to determine the Member State in which the supply is taxable, and may raise data protection issues, it is no longer included in the records to be kept by taxable persons using the One Stop Shop listed in Article 63c of the VAT implementing Regulation. Further information on returns of goods and consignment or transaction numbers are included in Article $63 \mathrm{c}$ to facilitate the control of those operations.

\subsection{Other Provisions}

Article 14 is deleted following the deletion of Article 34 of the VAT Directive by the VAT e-commerce Directive (Art. 1, point (2) of the proposal).

Article 2 provides that the measures shall apply from 1 January 2021, which is the date of application of the relevant provisions of the VAT e-commerce Directive which this proposal for an implementing Regulation as regards electronic interfaces and the special schemes for taxable persons supplying services implements. Furthermore, it provides for the possibility for taxable persons to register for the One Stop Shop as of 1 October 
2020 , to allow them to make use of it as of 1 January 2021.

\section{The Directive as Regards Harmonising and Simplifying Certain Rules in the VAT System; Directive (EU) 2018/1910}

\subsection{Introduction}

On 7 April 2016, the Commission published its Action Plan on VAT - Tomards a single EUVAT area - Time to decide (VAT Action Plan). ${ }^{33}$ The Commission announced, inter alia, its intention to adopt a definitive VAT system for intra-Union cross-border trade based on the principle of taxation in the Member State of destination of the goods in order to create a robust single European VAT area. A legislative proposal for such a simpler and fraud-proof definitive VAT system for intra-Union trade was included in the Commission Work Programme for 2017. ${ }^{34}$

In its conclusions on improvements to the current EU VAT rules for cross-border transactions of 8 November 2016, the Council stated that, while the Commission is working on the definitive VAT system for intra-Union trade, improvements to the current VAT system should be made in the meantime. In this context, the Council requested amendments in four areas ('quick fixes'): ${ }^{35}$

- Call-off stock: the Council invited the Commission to propose modifications to the current VAT rules in order to allow simplification and uniform treatment for call-off stock arrangements in cross-border trade. To this effect, 'call-off stock' refers to the situation where a vendor transfers goods to a warehouse at the disposal of a known acquirer in another Member State and that acquirer becomes the owner of the goods upon calling them off the warehouse;

- Chain transactions: the Commission was invited by the Council to propose uniform criteria and appropriate legislative improvements that would lead to increased legal certainty and harmonised application of VAT rules when determining the VAT treatment of chain transactions, including triangular transactions;

- VAT identification number: the Council invited the Commission to present a legislative proposal aimed at making the valid VAT identification number of the taxable person or non-taxable legal person acquiring the goods, allocated by a Member State other than

33. $\operatorname{COM}(2016) 148$ final, see section 1.14 .

34. $\operatorname{COM}(2016) 710$ final.

35. In December 2019 the Commission published Explanatory Notes on the EU VAT changes in respect of call-off stock arrangements, chain transactions and the exemption for intra-Community supplies of goods ("2020 Quick Fixes"). These are not discussed here. that in which dispatch or transport of the goods began, an additional substantive condition for the application of the exemption in respect of an intraCommunity supply of goods; and

- Proof of intra-Community supply: the Council invited the Commission to explore possibilities for a common framework of recommended criteria for the documentary evidence required to claim an exemption for intra-Community supplies. ${ }^{36}$

In order to meet the request of the Council, on 4 October 2017, the Commission published its 'Proposal for a Council Directive amending Directive 2006/112/EC as regards harmonising and simplifying certain rules in the value added tax system and introducing the definitive system for the taxation of trade between Member States ${ }^{37}$ covering the first three areas. The fourth area requires a modification of the VAT Implementing Regulation and is therefore subject to a separate proposal. ${ }^{38}$ On 4 December 2018, the ECOFIN Council adopted Directive (EU) 2018/1910 amending Directive 2006/112/EC 'as regards harmonising and simplifying certain rules in the value added tax system for the taxation of trade between Member States'.

The requested amendments by the Council are met in the Directive, for:

- Call-off stock; see Section 3.3;

- Chain transactions; see Sections 3.4 and 3.4.1;

- VAT identification number as substantive requirement; see Sections 3.5 and 3.5.1.

- The proof of intra-Community supply; see Sections 3.6 and 3.6.1.

- The proposed call-off stock amendments requires some amendments with regard to keeping a register; see Section 3.7.

Furthermore:

- The call-off stock amendments require some amendments with regard to keeping a register; see Section 3.8 and the VAT information and exchange system (VIES) listing; see Section 3.9.

- The measures to strengthen administrative cooperation in the field of VAT, which are necessary even for the by the Council requested improvements to the

36. On 20 June 2018, the Council of the European Union published a note concerning proposals introducing quick fixes and the definitive VAT system. As an annex to the note, the Council published the compromise text of the proposals, including an additional quick fix besides the original four. The 'fifth quick fix' relates to the cost-sharing exemption and would make the application of the exemption an option to Member States. This optional rule would be included under Title IX Chapter 3 of the VAT Directive, raising the question whether recent judgments of the Court of Justice of the European Union on this topic (for example, DNB Banka, C-326/15) would become obsolete. However, some Member States and the European Commission expressed their concerns regarding the inclusion of such a new rule. The compromise text otherwise corresponds to the original proposals and does not take into account the earlier suggestions of the European Parliament. The fifth quick fix was not adopted.

37. $\operatorname{COM}(2017) 569$. Originally, the amendments were meant to apply with effect from 1 January 2019.

38. $\operatorname{COM}(2017)$ 568. See Section 2.6. 
current VAT system are further discussed in Section 3.11 .

As follows from the second part of the title of the Proposal the Commission also wanted to introduce next to the simplification of certain rules in the VAT system (aspects of) the definitive system for the taxation of trade between Member States.

- Some of the requested amendments by the Council required in the believe of the Commission the introduction of a new status of taxable persons, the certified taxable person (CTP), see Section 3.2. The CTP has not made it to the Directive (EU) 2018/1910, see Section 3.2.1. The proposed introduction also required changes in the administrative cooperation in the field of VAT, see Section 3.2.2.

- The policy statement regarding the destination principle and reporting on the effects of the (as yet proposed) measures are dealt with in Section 3.10.

According to the Commission, a forthcoming proposal ${ }^{39}$ will further provide detailed technical provisions for the actual implementation of these cornerstones.

\subsection{The Proposal Regarding the Certified Taxable Person}

On 4 October 2017, the Commission presented its proposal for a directive amending the VAT Directive as regards harmonising and simplifying certain rules in the value added tax system and introducing the definitive system for the taxation of trade between Member States. ${ }^{40}$ The proposed Article 13 a provides that under certain conditions taxable persons ${ }^{41}$ should be able to obtain the status of a certified taxable person (CTP). The taxable person must have a place of business or a fixed establishment in the Community or, in the absence of a place of business and fixed establishment, must have his permanent address or usual residence in the Community. Furthermore, the taxable person must in the course of his economic activity carry out, or intend to carry out, any of the transactions referred to in Articles 17a (see Sections 3.3 and 3.3.1), 20 and 21 (dealing with intra-Community, and fictitious intra-Community acquisitions, of goods) or transactions in accordance with the conditions specified in Article 138 (exempt intra-Community supplies; see also Sections 3.5 and 3.5.1) in order to apply to the tax authorities for the status of CTP.

The concept of CTP should allow for an attestation that a particular business can globally be considered to be a reliable taxpayer. Certain simplification rules related to call-off stock arrangements (see Sections 3.3 and 3.3.1), chain transactions and the proof of transport of goods transported or dispatched to another Member State (see

39. See $\operatorname{COM}(2018) 329$ final of 25 May 2018, see Section 4.

40. $\operatorname{COM}(2017) 569$.

41. According to the preamble of the proposed directive (point 7), the creation of the CTP status is needed for the efficient application of the improvements to the Union VAT rules for cross-border transactions as well as for the gradual transition towards the definitive system for intraUnion trade.
Sections 3.4 and 3.4.1), which could be fraud sensitive, should apply only where CTPs are involved in the relevant transaction. ${ }^{42}$ The CTP concept should, in addition, allow for a gradual implementation of the definitive VAT system because during the first step of that definitive system reverse charge would apply where the acquirer, in the case of intra-Union supplies of goods, is a CTP. ${ }^{43}$ The justification is that since the CTP is, by definition, a reliable taxpayer, no fraud should occur as a result of VAT not being charged on intra-Union supplies of goods made for a CTP. ${ }^{44}$

Since the CTP status entails VAT reporting and payment obligations, non-taxable persons will not be eligible. For the same reason, the proposed Article 13a excludes flat-rate farmers, exempt SMEs, other taxable persons without the right to deduct input VAT and occasional taxable persons from the possibility of obtaining the CTP status. However, any SME not applying the exemption scheme will be able to apply for the CTP status under the same conditions as any other taxable person.

Similarity exists between the criteria to be used for granting the CTP status and those applied regarding the Authorised Economic Operator (AEO) as defined in the Union Customs Code (Art. 39 UCC). The proposed Article 13a provides that where the applicant is a taxable person who has been granted the status of an AEO for customs purposes, the criteria in paragraph 2 of Article 13 a shall be deemed to have been met.

The proposed Article 13a(2) provides that all the following criteria are required to be met in order to grant the status of a CTP:

- the absence of any serious infringement or repeated infringements of taxation rules and customs legislation, as well as of any record of serious criminal

42. According to the preamble of the proposed directive (point 6), given this demand and the fact that it will take several years for the definitive VAT system for intra-Union trade to be implemented, these specific measures, intended to harmonise and simplify certain arrangements for businesses, are appropriate.

43. As announced in the VAT Action Plan, in a future second legislative step of the definitive VAT system, taxation would cover all cross-border supplies of goods and services (and therefore the supplier, not the customer, would be liable for the VAT on all goods and services purchased from other Member States) so that all supplies of goods and services within the single market, either domestic or cross border, will be treated the same way.

44. According to the preamble of the proposed directive (point 8), in the current system no distinction is made between reliable and less reliable taxable persons as regards the VAT rules to be applied. The granting of the certified taxable person status on the basis of certain objective criteria should enable the identification of those reliable taxable persons. This status would allow them to benefit from the application of certain fraud-sensitive rules not applicable to other taxable persons. One may wonder whether the conditions to obtain the status of CTP, which are limited to intra-Union supplies of goods, would pass the equality requirement of Art. 20 of the Charter, since reliable taxpayers performing intra-Union supplies of services are excluded from this status, bearing in mind that the Court of Justice has held that equal treatment is not confined in tax matters to the principle of fiscal neutrality as between competing traders, but may be breached by other kinds of discrimination which affect traders who are not necessarily in competition with each other but who are nevertheless in a similar situation in other respects (Judgment of 25 April 2013, Commission v. Sweden, C-480/10, EU:C:2013:263, para. 17 and the case law cited). 
offences relating to the economic activity of the applicant;

- the demonstration by the applicant of a high level of control of its operations and of the flow of goods, either by means of a system of managing commercial and, where appropriate, transport records, which allows appropriate tax controls, or by means of a reliable or certified internal audit trail;

- evidence of financial solvency of the applicant, which shall be deemed to be proven either where the applicant has good financial standing, which enables it to fulfil its commitments, with due regard to the characteristics of the type of business activity concerned, or through the production of guarantees provided by insurance or other financial institutions or by other economically reliable third parties. ${ }^{45}$

Article 13a sets out the overall criteria on the basis of which the Member States will be able to certify taxable persons. Following the adoption of this proposal, a Council Implementing Regulation will have to be adopted, based on Article 397 of the VAT Directive, so as to arrange the practicalities of the CTP status and to ensure that the procedure for granting and withdrawing the CTP status is sufficiently harmonised and standardised throughout the Union so that a uniform application can be guaranteed. Also, an amendment to the Administrative Cooperation Regulation is proposed (see Section 3.2.2) in order to enable the CTP status of taxable persons being integrated in the VIES, thus allowing both tax administrations and businesses to verify online the CTP status of a particular business.

\subsubsection{The CTP Deleted from the Proposal?}

In the course of the negotiations on the 'VAT quick-fix' dossier, Member States deemed appropriate and necessary that the provisions of the Commission proposals relating to the CTP are discussed in the context of the legislative proposals on technical details of the definitive VAT system, which were tabled by the Commission on 25 May 2018; see Section 4. In this context, it was therefore deemed to be appropriate, in order to allow for early progress and to solve important issues in the VAT area, to advance the work on the core of the Commission proposals on the VAT 'quick-fix', while noting that the remaining parts of the proposals relating to the CTP will require further discussion, in the context of the legislative proposals on the details of the definitive system of VAT.

\subsubsection{Not Adopted Changes in the Administrative Cooperation in the Field of VAT Regarding the CTP}

On 4 October 2017, the Commission proposed amending Regulation (EU) No 904/2010, and, in particular, Articles 17 and 31 thereof, ${ }^{46}$ to apply from 1 January 2019 to CTPs.

45. It seems to us that the positive effect of this measure (especially compliance costs savings) might be limited, if one would base the effect on $E Y$ Study 2015 p. 98 stating that ' $0.3 \%$ of businesses within the EU will be eligible to apply for CTP'.

46. $\operatorname{COM}(2017) 567$ final
On 30 November 2017, the Commission presented yet another proposal for a Regulation amending Regulation (EU) No 904/2010. ${ }^{47}$ This legislative proposal constitutes an amended proposal including the provisions proposed on 4 October 2017.

The proposals regarding Articles 17 and 31 are discussed below. From the preamble of the proposed Regulation I derive the following.

The concept of CTP - as presented in Section 3.2 - is one of the essential components of the proposal on the definitive VAT system and will also be used for certain simplification measures within the current VAT system. The concept of the CTP should make it possible to prove that a specific taxable person can be considered as a reliable taxpayer within the Union.

Certain rules laid down by the VAT Directive for transactions that are considered fraud sensitive are to apply only where CTPs are involved - see Sections 3.3 and 3.4. It is therefore essential that the status of a CTP can be verified by electronic means in order to guarantee that those rules may apply.

As a first step towards a definitive VAT system as proposed in a Communication from the Commission on the 'Action plan on VAT - Towards a single EU VAT area - Time to decide', the reverse charge procedure is to apply to intra-Union supplies of goods where the person acquiring the goods is a CTP. It is therefore essential for taxable persons supplying goods within the Union to know whether or not their customers have been granted CTP status. Given the practical similarity to the current exemption for intra-Community supplies of goods, and to avoid unnecessary costs or burden, information on the CTP status should be provided by the VIES. In order to provide information on the CTP status of taxable persons in Member States, Member States should record and store the up-to-date status of taxable persons who have been granted certified taxable person status by a competent authority in that Member State, in an electronic system. The tax authorities in a Member State should then grant the tax authorities in other Member States automated access to this information. In addition, they should also be able, at the request of certain persons provided for in Regulation (EU) No 904/2010, to confirm by electronic means the CTP status of any taxable person where that status is relevant for those transactions. The proposed Articles 17 and 31 of the Regulation provide for the necessary amendments to comply with the above considerations.

In the course of the negotiations regarding the changes in the administrative cooperation in the field of $\mathrm{VAT}^{48}$ Member States deemed it appropriate, in order to allow

47. $\operatorname{COM}(2017) 706$ final.

48. On 2 October 2018, the Council adopted measures to strengthen administrative cooperation and to improve the prevention of VAT fraud. The regulation will tackle the most widespread forms of cross-border fraud by improving how tax administrations cooperate among themselves and with other law enforcement bodies. The Council reached political agreement on this file on 22 June 2018. The Parliament delivered its opinion on 3 July 2018. The regulation (not further discussed here) will enter into force twenty days after its publication in the Official Journal, with most of the provisions being applied as of 1 January 2020. 
for early progress in the field of administrative cooperation in the VAT area, to advance the work on the core of this Commission proposal. Therefore, in the future, the Council will continue to work on the elements of the Commission proposal relating to the CTP.

\subsection{Call-Off Stock; Proposal}

On 4 October 2017, the Commission presented its proposal for a directive amending the VAT Directive as regards harmonising and simplifying certain rules in the value added tax system and introducing the definitive system for the taxation of trade between Member States. ${ }^{49}$ The proposal deals, inter alia, with call-off stock.

Call-off stock is a scheme whereby a supplier transfers goods to a known acquirer without transferring the ownership of the goods yet. The acquirer has the right to take the goods from a stock of the supplier at his own discretion, at which point a supply of goods takes place. In domestic relationships, the use of this model does not create specific problems, but issues arise when the supplier and the acquirer are situated in different Member States.

Under the VAT rules, a business transferring own goods to another Member State in order to constitute a stock for a customer is deemed to have made a VATexempt supply of goods in the Member State of departure. The arrival of the goods gives rise to a deemed intra-Community acquisition made by the business that transferred the goods, which is subject to VAT in that other Member State. The business that has transferred the goods is obliged, as a rule, to be identified for VAT purposes in the Member State of arrival in order to be able to declare the intra-Community acquisition in its VAT return. ${ }^{50}$ When the goods are taken out of the stock and delivered to the acquirer, a second supply occurs, the place of supply of which is the Member State in which the stock is situated.

In order to address the difficulties that this can cause in practice, certain Member States apply simplification measures regarding these transactions, but others do not. These differences run against the uniform application of the VAT rules within the single market. ${ }^{51}$

The proposed solution (Art. 17a) consists of considering the call-off stock arrangements as giving rise to a single supply in the Member State of departure and to an intra-Community acquisition in the Member State where the stock is situated insofar as the transaction is taking place between two CTPs (see Section 3.2). ${ }^{52}$ This will avoid that the supplier has to be identified in every Member State where he has placed goods under the

49. $\operatorname{COM}(2017) 569$

50. Which may, nevertheless, be exempt if the subsequent 'domestic' supply is subject to the reverse charge and no other chargeable supplies of goods or services are performed by the deemed acquirer.

51. It seems to us that other simplification measures (than proposed in Art. 17a) are no longer permissible and that the supplier must account for a fictitious intra-Community acquisition when the call-off stock transaction is not taking place between two certified taxable persons.

52. The exempt intra-Community supply takes place when the recipient CTP calls off the (or part of the) stock that he then acquires. call-off stock arrangements. However, to ensure an adequate follow-up of the goods by the tax administrations, the supplier as well as the acquirer will be required to keep a register of call-off stock goods to which these rules apply (see Section 3.8). Further, in the recapitulative statement of the supplier, the identity of the acquirers to whom goods dispatched under call-off stock arrangements will be supplied at a later stage must be mentioned (see Section 3.9).

\subsubsection{Call-off Stock; Directive (EU) 2018/1910 as Finally Adopted}

On 4 December 2018, the ECOFIN Council adopted Directive (EU) 2018/1910 amending Directive 2006/112/EC "as regard harmonising and simplifying certain rules in the value added tax system for the taxation of trade between Member States". (Thus, omitting "and introducing the definitive system for the taxation of trade between Member States" as was in the title of the proposal.) An important change compared to the original proposals is that the involvement of certified taxable persons is not required for the application of the quick-fixes. This has the following consequence for the call-off stock: other than the requirement that the dispatching party should not be established in the Member State of arrival and the purchasing party should be registered for VAT purposes there are no further conditions regarding their status. The adopted text also introduces a 12-month deadline within which the goods need to be sold from the stockholder to the purchaser in order for the simplification to apply.

- $\quad$ Article 17a [Transfer under call-off stock arrangements]

According to Article 17a(1), as adopted, the transfer by a taxable person of goods forming part of his business assets to another Member State under calloff stock arrangement are not to be treated as a supply of goods for consideration.

- $\quad$ Conditions to qualify for call-off stock arrangements $(17 \mathrm{a}(2))$

For the purposes of this Article, call-off stock arrangements are deemed to exist where the following conditions are met:

- goods are dispatched or transported by a taxable person, or by a third party on his behalf, to another Member State with a view to those goods being supplied there, at a later stage and after arrival, to another taxable person who is entitled to take ownership of those goods in accordance with an existing agreement between both taxable persons;

- the taxable person dispatching or transporting the goods has not established his business nor has a fixed establishment in the Member State to which the goods are dispatched or transported;

- the taxable person to whom the goods are intended to be supplied is identified for VAT purposes in the Member State to which the goods are dispatched or transported and both his identity and the VAT identification number assigned to him by that Member 
State are known to the taxable person dispatching or transporting the goods at the time when the dispatch or transport begins;

- the taxable person dispatching or transporting the good record the transfer of the good in the register provided for in Article 243(3) (see Section 3.8) and include the identity of the taxable person acquiring the goods and the VAT identification number assigned to him by the Member State to which the goods are dispatched or transported in the recapitulative statement provided for in Article 262(2), see Section 3.9 .

- Applicable rules at the time of the transfer of the right to dispose of the goods as owner $(17 \mathrm{a}(3))$

Where these conditions are met, the following rules apply at the time of the transfer of the right to dispose of the good as owner to the identified taxable person to whom the goods are intended to be supplied is identified for VAT, provided that the transfer occurs within the 12-month deadline:

- a supply of goods in accordance with Article 138(1) is deemed to be made by the taxable person that dispatched or transported the goods either by himself or by a third party on his behalf in the Member State from which the goods were dispatched or transported;

- an intra-Community acquisition of goods shall be deemed to be made by the taxable person to whom those goods are supplied in the Member State to which the goods were dispatched or transported.

- $\quad$ Time-limit (17a(4))

As mentioned above, if within 12 months after the arrival of the goods in the Member State to which they were dispatched or transported, the goods have not been supplied to the taxable person for whom they were intended, or his substitution see Article 17a(6) below, and none of the of the conditions to qualify for call-off stock arrangements set out above and regarding substitution, see below, ceases to be fulfilled have occurred, a transfer within the meaning of Article 17 is deemed to take place on the day following the expiry of the 12-month period.

- $\quad$ Returned goods; no call-off transfer $(17 \mathrm{a}(5))$

No transfer to another Member State within the meaning of Article 17 is deemed to take place where the following conditions are met:

- the right to dispose of the goods has not been transferred, and those goods are returned to the Member State from which they were dispatched or transported within the 12-month time limit; and

- the taxable person who dispatched or transported the goods records their return in the register provided for in Article 243(3), see Section 3.8. (See also the requirements of keeping a register prescribed by Article 54a of the implementing Regulation in Section 3.6.1.)
- $\quad$ Substitution $(17 \mathrm{a}(6))$

Where, within the 12-month period, the taxable person to whom the goods are intended to be supplied is substituted by another taxable person, no transfers to another Member State, within the meaning of Article 17 , are deemed to take place at the time of the substitution, provided that:

- all other applicable conditions to qualify for call-off stock arrangements are met; and

- the substitution is recorded by the taxable person referred to in point (b) of paragraph 2 in the register provided for in Article 243(3), see Section 3.8.

- Non-fulfilment of the conditions to qualify for call-off stock arrangements or substitution (17a (7))

Where, within the 12-month time limit, any of the conditions to qualify for call-off stock arrangements or substitution set out above ceases to be fulfilled, a transfer of goods to another Member State, according to Article 17, is deemed to take place at the time that the relevant condition is no longer fulfilled. If the goods are supplied to a person other than the taxable person to whom the goods are intended to be supplied or his substitution, it is deemed that the conditions to qualify for call-off stock arrangements and substitution cease to be fulfilled immediately before such supply. If the goods are dispatched or transported to a country other than the Member State from which they were initially moved, it is deemed that those conditions cease to be fulfilled immediately before such dispatch or transport starts. In the event of the destruction, loss or theft of the goods it is deemed that those conditions cease to be fulfilled on the date that the goods were actually removed or destroyed, or, if it is impossible to determine that date, the date on which the goods were found to be destroyed or missing. (See also the requirement of keeping a register prescribed by Article 54a of the implementing Regulation in Section 3.6.1)

\subsection{Chain Transactions and the Proof of Transport; Proposal}

On 4 October 2017, the Commission presented its proposal for a directive amending the VAT Directive as regards harmonising and simplifying certain rules in the value added tax system and introducing the definitive system for the taxation of trade between Member States. ${ }^{53}$ The proposal deals, inter alia, with chain transactions.

Chain transactions are understood as successive supplies of the same goods where the goods supplied are subject to a single intra-Community transport between two Member States, see point 13 of the preamble of the proposed directive. In this situation, according to the $E M A G$ case, C-254/08, the transport is to be attributed to one supply within the chain so as to determine the transactions to which the exemption for intra-Community supplies should be applied in accordance with Article 
138 of the VAT Directive. The other supplies in the chain should be taxed and may require the VAT identification of the supplier in the Member State of supply. In order to avoid different approaches among Member States, which may lead to double or non-taxation, and in order to enhance legal certainty for operators, a common rule should be established, namely that provided certain conditions are met, the transport of the goods should be attributed to one supply within the chain of transactions. Article 138 stipulates, as a condition for the exemption, that the goods are 'dispatched or transported by or on behalf of the vendor or the person acquiring the goods' from one Member State to another. In this context, Member States have asked for legislative improvements in order to increase legal certainty for operators in determining the supply within the chain of transactions to which the intra-Community transport must be ascribed (which will be the supply within the chain to which the exemption laid down in Article 138 will be applicable, provided all the other conditions for that exemption are met).

The proposed Article 138a foresees a simplification in chain transaction situations, meaning situations where successive supplies of the same goods by taxable persons give rise to a single intra-Community transport of those goods and where both the intermediary operator (meaning a supplier in the chain other than the first supplier, who dispatches or transports the goods, himself or by a third party on his behalf) and the provider (meaning the taxable person in the chain who supplies the goods to the intermediary operator) are $C T P S$ (see Section 3.2). It is proposed that for the purposes of applying the exemptions in Article 138 in the context of a chain transaction situation, the intra-Community transport is to be ascribed to the supply made by the provider to the intermediary operator, both CTPs,${ }^{54}$ where the following conditions are met:

- the intermediary operator communicates the name of the Member State of arrival of the goods to the provider;

- the intermediary operator is identified for VAT purposes in a Member State other than that in which the dispatch or transport of the goods begins. ${ }^{55}$

Where any of the above conditions is not met, in a chain transaction situation the intra-Community transport must be ascribed to the supply made by the intermediary operator to the customer (meaning the taxable person to whom the intermediary operator supplies the goods in the chain).

54. It is not excluded that, in case of involvement of a non-CTP, the transport could be ascribed to the same supply. However, in that case the legal rules in Art. 138a will not apply, and thus it remains, in the same way as under the current conditions, for the taxable person concerned to demonstrate that the transport and the exemption are linked to that particular supply.

55. No rule of this kind is needed where the transport is made on behalf of the first supplier in the chain (in which case the transport can only be ascribed to the first supply) or on behalf of the last taxable person in the chain (in which case the transport can be ascribed only to the supply made for that taxable person).

\subsubsection{Chain Transactions and the Proof of Transport;}

Directive (EU) 2018/1910 as Finally Adopted

On 4 December 2018, the ECOFIN Council adopted Directive (EU) 2018/1910 amending Directive 2006/112/EC "as regards harmonising and simplifying certain rules in the value added tax system for the taxation of trade between Member States".

The proposed Article 138a is replaced by a new Article 36 a.

An important change compared to the original proposals is that the involvement of a CTP is not required for the application of the quick-fixes. This has the following consequences for chain transactions: there will be a legal assumption that the intra-Community supply is performed to the middleman party organising the transport of goods, unless the middleman party informs the dispatching party about its VAT identification number in the Member State of dispatch in which case it must be ascribed only to the supply of goods by the intermediary operator.

- $\quad$ Article 36a [Intermediary operator]

According to Article 36a, where the same goods are supplied successively and those goods are dispatched or transported from one Member State to another Member State directly from the first supplier to the last customer in the chain, the dispatch or transport must be ascribed only to the supply made to the intermediary operator. For the purposes of this Article, 'intermediary operator' means a supplier within the chain other than the first supplier in the chain who dispatches or transports the goods either himself or through a third party acting on his behalf.

By way of derogation from the above, the dispatch or transport must be ascribed only to the supply of goods by the intermediary operator where the intermediary operator has communicated to his supplier the VAT identification number issued to him by the Member State from which the goods are dispatched or transported.

This Article is not applicable to the situations covered by Article 14a, i.e. the facilitation of distance sales of imported goods (applicable from 1 January 2021).

\subsection{Amending Article 138(1); New Substantive Conditions; Proposal}

On 4 October 2017, the Commission presented its proposal for a directive amending the VAT Directive as regards harmonising and simplifying certain rules in the value added tax system and introducing the definitive system for the taxation of trade between Member States. ${ }^{56}$ With regard to the VAT identification number and the exemption for certain intra-Community transactions, an amended Article 138(1) is proposed. As mentioned in Section 3.1, the Member States have requested the inclusion in the VAT Directive of the requirement for a valid VAT identification number of the acquirer in a Member State other than that in which 
transport of the goods begins as a substantive condition in order for the supplier to be allowed to apply the exemption. This goes further than the current situation under which, according to the interpretation of the Court of Justice (see Mecsek-Gabona, C-273/11, VSTR, C-587/10, Plöckl, C-24/15, and Euro-Tyre II, C-21/16), the VAT identification number of the acquirer is simply a formal condition of the right to exempt an intra-Community supply. That leads to situations where, when the condition has not been complied with, Member States are only able to impose fines or administrative sanctions but not to refuse the exemption itself.

The current transitional arrangements are further based on the obligation for the supplier to submit a recapitulative statement (the so-called VIES listing that includes the VAT identification number of the acquirer). This is again a formal but not a substantive condition in relation to the exemption. This information is, via the VIES system, accessible for the tax authorities of the Member State of the acquirer which is thus informed of the arrival in its territory of goods that are normally subject to a taxed intra-Community acquisition. The acquirer has to declare this intra-Community acquisition in his VAT return, and the tax authorities have the possibility to cross-check this declaration with data in the VIES system. The VIES listing has therefore been a crucial component of the VAT system since the abolition of the fiscal borders and the corresponding disappearance of the customs documentation.

Without correct information from the VIES system, the tax authorities of the Member States are not duly informed of the arrival of untaxed goods in their territory and have solely to rely on what their taxable persons declare. Nevertheless, if the listing is not filled in as regards a supply, this can give rise to penalties but not to the rejection of the exemption as such. The new proposed Article 138(1) therefore includes changes as regards these two aspects.

First, whereas currently reference is made to the acquirer as a taxable person or a non-taxable legal person acting as such, it is now stipulated, as a substantive condition for the application of the exemption, that the acquirer has to be identified for VAT purposes in a Member State other than that in which dispatch or transport of the goods begins. As already happens today, the supplier will have to verify the status of his customer via the VIES system before applying the exemption. From that perspective, there is no practical difference for the supplier, but the consequences might be different as the non-identification of his customer can, on that basis, lead to a rejection of the exemption.

Secondly, also the correct filing of the VIES listing becomes a substantive condition that can lead, where that condition is not met, to the rejection by the tax administration of an applied exemption.

\subsubsection{Amending Article 138(1), Nem Substantive Conditions; Directive (EU) 2018/1910 as Finally Adopted}

On 4 December 2018, the ECOFIN Council adopted Directive (EU) 2018/1910 amending Directive 2006/112/EC "as regards harmonising and simplifying certain rules in the value added tax system for the taxation of trade between Member States".

With regard to the proposed substantive conditions of zero-rating intra-Community supplies of goods, the rules essentially remain unchanged, i.e. for the VAT zero rate to apply, the goods need to be transported from one Member State to the other, the purchasing party needs to have a valid VAT identification number in the Member State of arrival and the supplier needs to file a correct recapitulative statement regarding the supply. ${ }^{57}$

From 1 January 2020, Article 138(1) is replaced by the following:

Member States must exempt the supply of goods dispatched or transported to a destination outside their respective territory but within the Community, by or on behalf of the vendor or the person acquiring the goods, where the following conditions are met:

- the goods are supplied to another taxable person, or to a non-taxable legal person acting as such in a Member State other than that in which dispatch or transport of the goods begins;

- the taxable person or non-taxable legal person for whom the supply is made is identified for VAT purposes in a Member State other than that in which the dispatch or transport of the goods begins and has indicated this VAT identification number to the supplier.

The following paragraph $1 \mathrm{a}$ is inserted, providing that the exemption provided for above does not apply where the supplier has not complied with the obligation provided for in Articles 262 and 263 to submit a recapitulative statement or the recapitulative statement submitted by him does not set out the correct information concerning this supply as required under Article 264 see Section 3.9 unless the supplier can duly justify his shortcoming to the satisfaction of the competent authorities.

\subsection{Proof of Intra-Community Supply}

(Implementing Regulation); Proposal

Also on 4 October 2017, the Commission proposed amending Implementing Regulation (EU) No 282/2011

57. At this place we note that the Court in Enteco Baltic, C-108/17, noted that Directive 2009/69 did not amend Art. 143(1)(d) of the VAT Directive, which refers to the substantive conditions for the exemption of the ensuing intra-Community supply laid down in Art. 138 of that directive. The Court added that to adopt a contrary interpretation of that provision would be incompatible with the fact that the exemption on importation is subject to compliance with the conditions for the exemption of the subsequent intra-Community supply and in the absence of amendment to the latter conditions - in particular Art. 138 of the VAT Directive - by Directive 2009/69, would produce inconsistencies in the system of those exemptions. 
to introduce the harmonisation and simplification of rules on the proof of the intra-Community transport of the goods in order to exempt from VAT an intra-Community supply of goods. ${ }^{58}$ This simplification would be available only where a CTP (see Section 3.2) is involved. The proposal (Art. 45a of the Implementing Regulation) consists of introducing a rebuttable presumption in two specific cases that involve the CTP status. ${ }^{59}$

In the first situation, whereby the goods have been transported or dispatched by the supplier, directly or by a third party on his behalf, and the supplier has the CTP status, a presumption is introduced according to which the goods have been transported from the Member State of supply (departure) to another Member State in case the supplier is in possession of two noncontradictory documents (a list of which is contained in the Regulation ${ }^{60}$ ) attesting to the transport. However, a tax authority may rebut this presumption on the basis of evidence indicating that the goods were not transported from the Member State of supply to another Member State.

In the second situation, where the customer is a CTP and where the goods have been transported or dispatched by that customer, directly or by a third party on his behalf, a presumption is introduced according to which the goods can be regarded as transported from the Member State of supply to another Member State if the supplier is in possession of (i) a written statement by the acquirer that the goods have been transported by the acquirer or on his behalf with mention of the Member State of arrival of the goods (without, however, the need to disclose the exact destination in order to preserve the confidentiality of the acquirer's business); and (ii) two noncontradictory documents (of those mentioned in the list

58. $\operatorname{COM}(2017) 568$

59. According to the preamble to the proposed Regulation (points 2-5): The VAT Directive sets out a number of conditions to exempt from VAT supplies of goods in the context of certain intra-Community transactions. One of those conditions is that the goods have to be transported or dispatched from one Member State to another.

However, the divergent approach among Member States in the application of these exemptions for cross-border transactions has created difficulties and legal uncertainty for businesses. This is contrary to the objective of enhancing intra-Union trade and to the abolition of the fiscal borders. It is therefore important to specify and harmonise the conditions under which the exemptions can apply.

As cross-border VAT fraud is linked primarily to the exemption for intraCommunity supplies, it is necessary to specify certain circumstances in which goods should be considered as having been transported or dispatched from the territory of the Member State of supply.

In order to provide a practical solution for businesses and also assurance for tax administrations, two rebuttable presumptions are introduced in respect of transactions involving CTPs in Implementing Regulation (EU) No 282/2011.

60. Art. $24 \mathrm{f}$ provides that the following shall, in particular, serve as evidence:

a. the billing address of the customer;

b. bank details such as the place where the bank account used for payment is and the billing address of the customer held by that bank;

c. the Mobile Country Code (MCC) of the International Mobile Subscriber Identity (IMSI) stored on the Subscriber Identity Module (SIM) card used by the customer;

d. the location of the customer's fixed landline through which the service is supplied to him;

e. other commercially relevant information. contained in the Regulation ${ }^{61}$ ) attesting to the transport. The statement in (i), which is to be recorded by the supplier, has to be provided no later than on the 10th day of the month following the supply. This period should give the acquirer sufficient time to transmit the information while, at the same time, it does not exceed the time limit for the supplier to issue an invoice (at the latest on the 15th of the month following the supply in accordance with the conditions of Article 222 of the VAT Directive). ${ }^{62}$

\subsubsection{Proof of Intra-Community Supply and the Register (Implementing Regulation); Regulation (EU) 2018/1912 as Finally Adopted}

On 4 December 2018, the ECOFIN Council adopted the four adjustments to the EU's current VAT rules to fix specific issues. An important change compared to the original proposals is that the involvement of certified taxable persons is not required for the application of the quick-fixes. This has the following consequences for documentary evidence of zero-rating intra-Community supplies of goods as dealt with in the implementing Regulation amended by Regulation (EU) 2018/1912.

A new section 2A entitled "Exemptions for intra-Community transactions (Art. 138 to 142 of Directive 2006/112/EC)"

- Article 45a [Presumption of an exempt intraCommunity supply]

According to Article 45a(1) of the implementing Regulation, for the purpose of applying the exemptions laid down in Article 138 of the VAT Directive, it is to be presumed (a presumption which a tax authority may rebut) that goods have been dispatched or transported from a Member State to a destination outside its territory but within the Community in either of the following cases:

- the vendor indicates that the goods have been dispatched or transported by him or by a third party on his behalf, and either the vendor is in possession of at least two items of non-contradictory evidence referred to in the first indent on evidence below which were issued by two different parties that are independent of each other, of the vendor and of the acquirer, or the vendor is in possession of any single item referred to in the first indent on evidence below together with any single item of non-contradictory evidence referred to in the second indent on evidence below confirming the dispatch or transport which were issued by two different parties that are independent of each other, of the vendor and of the acquirer;

- the vendor is in possession of the following: a written statement from the acquirer, stating that the goods have been dispatched or transported by the acquirer, or by a third party on behalf of the acquirer, and

61. Ibid.

62. For the situations that are not covered by these presumptions, e.g. because the taxable persons involved do not have the CTP status, the rules, as interpreted by the Court of Justice, remain applicable. 
identifying the Member State of destination of the goods; that written statement shall state: the date of issue; the name and address of the acquirer; the quantity and nature of the goods; the elate and place of the arrival of the goods; in the case of the supply of means of transport, the identification number of the means of transport; and the identification of the individual accepting the goods on behalf of the acquirer (the acquirer must furnish the vendor with the written statement referred to above by the tenth clay of the month following the supply); and at least two items of non-contradictory evidence referred to in the first indent on evidence below that were issued by two different parties that are independent of each other, of the vendor and of the acquirer, or any single item referred to in the first indent on evidence below together with any single item of non-contradictory evidence referred to in the second indent on evidence below confirming the dispatch or transport which were issued by two different parties that are independent of each other, of the vendor and of the acquirer.

\section{- $\quad$ Evidence}

According to Article 45a(2) of the implementing Regulation, for the purposes of paragraph 1, the following is to be accepted as evidence of dispatch or transport:

- documents relating to the dispatch or transport of the goods, such as a signed CMR document or note, a bill of lading, an airfreight invoice or an invoice from the carrier of the goods;

- the following documents:

- an insurance policy with regard to the dispatch or transport of the goods, or bank documents proving payment for the dispatch or transport of the goods;

- official documents issued by a public authority, such as a notary, confirming the arrival of the goods in the Member State of destination;

- a receipt issued by a warehouse keeper in the Member State of destination, confirming the storage of the goods in that Member State.

Furthermore after 54 of the implementing Regulation Section 1A is inserted entitled "General obligations (Art. 242 to 243 of Directive 2006/112/EC)" dealing with the register see also Section 3.8.

- $\quad$ Article 54a [Keeping a register; transfers goods under call-off stock arrangements]

According to Article 54a(1), the register referred to in Article 243(3) of the VAT Directive that is to be kept by every taxable person who transfers goods under call-off stock arrangements must contain the following information:

- the Member State from which the goods were dispatched or transported, and the date of dispatch or transport of the goods;

- the VAT identification number of the taxable person for whom the goods are intended, issued by the Member State to which the goods are dispatched or transported;
- the Member State to which the goods are dispatched or transported, the VAT identification number of the warehouse keeper, the address of the warehouse at which the goods are stored upon arrival, and the date of arrival of the goods in the warehouse;

- the value, description and quantity of the goods that arrived in the warehouse;

- the VAT identification number of the taxable person substituting for the person for whom the goods are intended, under the conditions referred to in Article 17a(6) of the VAT Directive, see Section 3.3.1;

- the taxable amount, description and quantity of the good supplied and the date on which the supply of the goods referred to in Article $17 \mathrm{a}(3)$ of the VAT Directive is made and the VAT identification number of the buyer, see Section 3.3.1;

- the taxable amount, description and quantity of the goods, and the date of occurrence of any of the conditions and the respective ground in accordance with Article $17 \mathrm{a}(7)$ of the VAT Directive, see Section 3.3.1;

- the value, description and quantity of the returned goods and the date of the return of the goods referred to in Article 17a(5) of the VAT Directive, see Section 3.3.1.

According to Article 54a(2), the register referred to in Article 243(3) of the

VAT Directive that is to be kept by every taxable person to mhom goods are supplied under call-of stock arrangements shall contain the following information:

- the VAT identification number of the taxable person who transfers goods under call-off stock arrangements;

- the description and quantity of the goods intended for him;

- the date on which the goods intended for him arrive in the warehouse (where the goods are dispatched or transported under call-off stock arrangements to a warehouse keeper different from the taxable person for whom the goods are intended to be supplied, the register of that taxable person does not need to contain this information);

- the taxable amount, description and quantity of the goods supplied to him and the date on which the intra-Community acquisition of the goods referred to in Article 17a(3) of the VAT Directive is made, see Section 3.3.1;

- the description and quantity of the goods, and the date on which the goods are removed from the warehouse by order of the taxable person who transfers goods under call-off stock arrangements (where the goods are dispatched or transported under call-off stock arrangements to a warehouse keeper different from the taxable person for whom the goods are intended to be supplied, the register of that taxable person does not need to contain this information);

- the description and quantity of the goods destroyed or missing and the date of destruction, loss or theft of the goods that previously arrived in the warehouse or 
the elate on which the goods were found to be destroyed or missing (where the goods are dispatched or transported under call-off stock arrangements to a warehouse keeper different from the taxable person for whom the goods are intended to be supplied, the register of that taxable person does not need to contain this information).

\subsection{The Fifth Quick Fix; Not Adopted}

Some delegations have repeatedly requested that the (Bulgarian) Presidency ${ }^{64}$ compromise text of the Commissions' proposal is supplemented with an additional amendment to the VAT Directive and Article 137a is inserted, as part of an overall compromise on this dossier.

This new Article 137a of the VAT Directive would, essentially, contain a rule, with appropriate safeguards against distortion of competition, permitting an option for Member States to provide that independent groups of persons that pool their services and share costs between their members benefit from VAT exemption.

Some delegations indicated that such an optional rule would only be acceptable if it is accompanied by an appropriate 'territorial clause' (Art. 137a(2)), limiting the scope of this optional cost-sharing mechanism only to independent group of persons and its members established within the territory of the Member State that avails itself of that option.

These delegations are of the view that such a limitation would be justified by the need to ensure correct and straightforward application of these rules on cost-sharing by the taxable persons concerned and tax administrations, as well as guarantee the effectiveness of fiscal supervision against risks of tax evasion, avoidance or abuse. At the same time, this limitation would preserve the taxing rights of Member States that choose not to exercise this option.

Nevertheless, at the meeting of the Committee of Permanent Representatives on 14 June and 20 June 2018, some delegations could not accept that Article 137a is inserted into the VAT Directive, while indicating that this provision was not subject to an impact assessment by the Commission, since Article 137a and recital 7a were not part of the initial legislative proposal.

On 4 December 2018, the ECOFIN Council adopted the four adjustments to the EU's current VAT rules to fix specific issues omitting the fifth quick fix.

\subsection{Keeping a Register}

Article 243 introduces special obligations (inter alia, keeping a register) with regard to temporary intra-Community movements of goods, providing that every taxable person must keep a register of the goods dispatched or transported, by that person or on his behalf, to a destination outside the territory of the Member State of departure but within the Community for the purposes of transactions consisting in work on those goods or their temporary use as referred to in points (f), (g) and (h) of Article 17(2) (i.e. (f) the supply of a service performed for the taxable person and consisting of valua- tions of or work on the goods in question physically carried out within the territory of the Member State in which dispatch or transport of the goods ends, (g) the temporary use of the goods within the territory of the Member State in which dispatch or transport of the goods ends, (h) for the purposes of the supply of services, the temporary use of the goods, for a period not exceeding 24 months, within the territory of another Member State). Furthermore, every taxable person must keep accounts in sufficient detail to enable the identification of goods dispatched to him from another Member State, by or on behalf of a taxable person identified for VAT purposes in that other Member State, and used for services consisting in valuations of those goods or work on those goods.

Based on the adopted text regarding call-off stock (see Section 3.3.1), the Directive prescribes, in a paragraph added to Article 243, that every taxable person who transfers goods under the call-off stock arrangements referred to in Article 17a must keep a register of the following:

- the goods dispatched or transported to another Member State and the address where they are stored in this Member State; and

- the goods supplied at a later stage and after arrival in that Member State.

Every taxable person to whom goods are supplied under the call-off stock arrangements referred to in Article 17a must keep a register of those goods. For the details see Article 54a of the implementing Regulation Section 3.6.1.

\subsection{VIES Listing}

Article 262 of the VAT Directive, as amended by Directive 2008/8/EC, obliges suppliers of services (other than those that are exempted from VAT) to taxable persons, who are required to account for the VAT under the reverse charge mechanism pursuant to the amended Article 196, to include those taxable persons and nontaxable legal persons identified for VAT purposes in their recapitulative statement (VIES listing).

Based on the adopted text regarding call-off stock (see Section 3.3.1), Directive (EU) 2018/1910 prescribes in a paragraph added to Article 262 that in addition every taxable person must submit information about the VAT identification number of the taxable persons for whom goods, dispatched or transported under call-off stock arrangements in accordance with the conditions set out in Article 17a, are intended and about any change in the submitted information. See also Article 138(1a) in Section 3.5.1, providing that the exemption for intra-Community supplies does not apply where the supplier has not complied with the obligation provided for in Articles 262 and 263 to submit a recapitulative statement or the recapitulative statement submitted by him does not set out the correct information concerning this supply as required under Article 264, unless the supplier can duly justify his shortcoming to the satisfaction of the competent authorities. 
See also in Section 3.11 Council Regulation (EU) 2018/1909 of 4 December 2018 amending Regulation (EU) No $904 / 2010$ as regards the exchange of information for the purpose of monitoring the correct application of call-off stock arrangements ensuring that the simplification introduced in the VAT Directive as regards call-off stock arrangements can be monitored properly, by granting the relevant competent authorities of the Member States to have automated access to the data collected from taxable persons as regards such transactions.

\subsection{Policy Statement, Towards the 'Intra-Union Supply' Not Yet Adopted}

Article 402 contains the following 'policy statement':

The arrangements provided for in this Directive for the taxation of trade between Member States are transitional and shall be replaced by definitive arrangements based in principle on the taxation in the Member State of origin of the supply of goods or services.

According to Article 402(2), having concluded, upon examination of the report referred to in Article 404, that the conditions for transition to the definitive arrangements are met, the Council, acting in accordance with Article 113 TFEU, i.e. unanimously, is to adopt the provisions necessary for the entry into force and for the operation of the definitive arrangements.

On 4 October 2017, the Commission presented its proposal for a directive amending the VAT Directive as regards harmonising and simplifying certain rules in the value added tax system and introducing the definitive system for the taxation of trade between Member States. ${ }^{63}$

The proposed Article 402 of the Directive establishes that the VAT definitive system for intra-EU trade will be based on the principle of taxation in the Member State of destination of the supply of goods and services. In this context, a new concept in relation to goods - the so-called intra-Union supply - will be introduced in the announced detailed technical provisions (see Section 4.1.3). This new single taxable event is intended to replace the current system of an exempt supply in the Member State of departure and a taxed intra-Community acquisition' in the Member State of destination as a second and separate taxable event. Under this new concept, the 'place of supply' will be situated in the Member State of arrival of the goods.

Concerning the amendments to Article 402 of the VAT Directive proposed by the Commission, following the meeting of the Committee of Permanent Representatives of 14 June 2018, and of 20 June 2018, all delegations, as well as the Commission, could agree, in the spirit of a compromise, that amendments to Article 402 of the VAT Directive are deleted from the text. These discussions will take place in the context of the legislative

63. $\operatorname{COM}(2017) 569$ proposals on the details of the definitive system of VAT. It is important to note that in its conclusions on the Commission 2016 Action Plan on VAT the Council, inter alia, reiterated that 'the principle of taxation in the Member State of origin of the supply of goods or services', as envisaged in Article 402 of Directive 2006/112/EC on the common system of value added tax, should be replaced by the principle of 'taxation in the Member State of destination' for the definitive VAT system for B2B transactions, as stated in the Council conclusions of 15 May 2012.

Article 403 instructs the Council, acting in accordance with Article 113 TFEU, to adopt provisions appropriate for the purpose of supplementing the common system of VAT and, in particular, for the progressive restriction or the abolition of derogations from that system. (It is proposed - and adopted in Directive (EU) 2018/1910 that Art. 403 is deleted.)

In Article 404, the Commission is instructed to present every 4 years starting from the adoption of the Recast VAT Directive, on the basis of information obtained from the Member States, a report to the European Parliament and to the Council on the operation of the common system of VAT in the Member States and, in particular, on the operation of the transitional arrangements for taxing trade between Member States. 'That report shall be accompanied, where appropriate, by proposals concerning the definitive arrangements.' (It is proposed - and adopted in Directive (EU) 2018/1910 - that Art. 404 is deleted.)

\subsection{Measures to Strengthen Administrative} Cooperation in the Field of VAT; Regulation (EU) 2018/1909

On 5 December 2017, the Council adopted Regulation (EU) No 2017/2454 amending Regulation (EU) No 904/2010. ${ }^{64}$ The extension from 1 January 2021 of the special schemes to distance sales of goods and services other than TBE services requires extending the scope of the rules of the Regulation, inter alia, concerning the provision of information between the Member State of identification and the Member States of consumption with effect from 1 January $2021 .{ }^{65}$

On 4 October 2017, the Commission proposed amending Regulation (EU) No 904/2010, and in particular Articles 17 and 31 thereof, ${ }^{66}$ to apply from 1 January 2019 to certified taxable persons, which has been put on hold (see Section 3.2.1).

On 4 December 2018, the ECOFIN Council adopted Council Regulation (EU) 2018/1909 amending Regulation (EU) No 904/2010 as regards the exchange of information for the purpose of monitoring the correct application of call-off stock arrangements.

Article 21(1) of the Regulation on administrative cooperation in the field of VAT stipulates that every Member State shall grant the competent authority of any

64. For the Proposal see $\operatorname{COM}(2016) 755$ final.

65. See also the report from the Commission on the application of Council Regulation (EU) No 904/2010: $\operatorname{COM(2014)~} 71$.

66. 164. $\operatorname{COM}(2017) 567$ final. 
other Member State automated access to the information stored pursuant to Article 17. According to Article 21(2), with respect to the information referred to in Article 17(1)(a), at least inter alia the following details shall be accessible:

(c) the VAT identification numbers of the persons who carried out the supplies of goods and services referred to in point (b);

Regulation (EU) 2018/1909 replaces point (c) by the following (changes in italics):

(c) the VAT identification numbers of the persons who carried out the supplies of goods and services referred to in point (b) and the VAT identification numbers of the persons who submitted information in accordance with Article 262(2) of Directive $2006 / 112 / E C^{67}$ about the persons holding a VAT identification number referred to in point (a); According to the introductory wording of point (e) (e) the total value of the supplies of goods and services referred to in point (b) from each person referred to in point (c) to each person holding a VAT identification number issued by another Member State under the following conditions [...]

Regulation (EU) 2018/1909 replaces the introductory wording in point (e) (changes in italics):

(e) the total value of the supplies of goods and services referred to in point (b) from each person referred to in point (c) to each person holding a VAT identification number issued by another Member State and, for each person who submitted information in accordance with Article 262(2) of Directive 2006/112/EC, his VAT identification number and the information he submitted about each person holding a $V A T$ identification number issued by another Member State, under the following conditions [...]

\section{The Proposal Introducing Detailed Measures of the Definitive VAT System}

\subsection{Introduction}

In its Action Plan on VAT - Tomards a single EU VAT area - Time to decide ${ }^{68}$ (VAT Action Plan, see Section 1) the Commission announced, inter alia, its intention to adopt a definitive VAT system for intra-Union crossborder trade based on the principle of taxation in the Member State of destination in order to create a robust single European VAT area. The Commission subsequently adopted a Communication on the follow-up to the VAT Action Plan Tomards a single EU VAT area-

67. According to Art. 262(2) of the VAT Directive, every taxable person shall submit information about the VAT identification number of the taxable persons for whom goods, dispatched or transported under calloff stock arrangements in accordance with the conditions set out in Art. $17 \mathrm{a}$, are intended and about any change in the submitted information.

68. $\operatorname{COM}(2016) 148$ final.
Time to $a c t^{69}$ in which it spelled out the gradual steps to be taken in the move towards that single European VAT area.

Besides the change to the definitive VAT system for cross-border trade, this move includes two other proposals to modify the VAT Directive: one as regards $\mathrm{VAT}_{\text {rates }}{ }^{70}$ and the other as regards the special scheme for small enterprises. ${ }^{71}$ In addition, it includes a proposal for a Council Regulation on combating fraud in the field of $\mathrm{VAT}^{72}$ As regards the change towards a definitive VAT system based on the principle of taxation in the Member State of destination, a gradual two-step approach was announced: a first step settling intraUnion B2B supplies of goods and a second step covering supplies of services.

The first step was further divided into two sub-steps. The first sub-step, presented simultaneously with the Communication, was a legislative proposal that outlined the cornerstones for a simpler and fraud-proof definitive VAT system for intra-Union trade. ${ }^{73}$ The current 'Proposal for a Directive amending the VAT Directive introducing detailed measures of the definitive VAT system' ${ }^{74}$ represents the second sub-step. It contains the detailed arrangements to put these cornerstones in place for intra-Union B2B supplies of goods.

The present proposal will need to be complemented by a proposal for amending Regulation (EU) 904/2010 on administrative cooperation in the field of value added tax. The latter proposal is of a technical nature as it would consist in aligning the cooperation between Member States to the proposed changes to the VAT system for cross-border supplies of goods. This proposal will be made sufficiently in time to allow for its adoption and implementation on the date of entry into force of the present proposal.

\subsubsection{Implementation Plan}

Member States are to adopt and publish, by 30 June 2022 at the latest, the laws, regulations and administrative provisions necessary to comply with the directive introducing the detailed technical measures. They must apply those provisions from 1 July 2022.

In its Communication of October 2017 on the follow-up to the VAT Action Plan, the Commission indicated that the implementation of the second step (covering crossborder services) in the gradual move to the definitive VAT system would be proposed by the Commission after due monitoring of the implementation of the first step (completed by the current proposal), the functioning of which in terms of robustness against fraud, of

69. $\operatorname{COM}(2017) 566$ final.

70. $\operatorname{COM}(2018) 20$ final. Not discussed here.

71. $\operatorname{COM}(2018) 21$ final. Not discussed here.

72. Amended proposal for a Council Regulation amending Regulation (EU) No 904/2010 as regards measures to strengthen administrative cooperation in the field of value added $\operatorname{tax}(\operatorname{COM}(2017) 706$ final). On 22 June 2018, the Council agreed on measures to strengthen administrative cooperation in order to improve the prevention of VAT fraud. Not discussed here.

73. $\operatorname{COM}(2017) 569$ final, see Section 3.

74. $\operatorname{COM}(2018) 329$ final 
compliance costs for businesses and of effectiveness in the management of the system by the tax authorities would be evaluated by the Commission 5 years after its entry into force.

To that purpose, the Commission will seek to obtain from Member States any relevant information concerning the level and the evolution of the administrative costs and of fraud. The Commission will also seek to collect input from all relevant business stakeholders concerning the level and the evolution of their compliance costs.

\subsubsection{Monetary Impact}

For all businesses, the monetary impact of the implementation is estimated to increase business costs, such as cost for updating the accounting and invoicing software and for professional training, by EUR 457 million in the year of implementation because of the need for business to adapt their internal procedures to the new rules, but results in a net business decrease of VAT compliance costs by EUR 938 million annually after the year of implementation. ${ }^{75}$

\subsubsection{Changes in Earlier Adopted and Proposed Amendments}

Certain changes concern provisions for which amendments are already proposed in the proposal COM(2017) 569 final of 4 October 2017 and partially adopted by Directive (EU) 2018/1910; see Section 3. That proposal provides, in response to a request from the Council, for improvements to the current VAT system to be made while the work on the definitive VAT arrangements for intra-Union trade is ongoing. The proposed changes for the so-called quick fixes remain entirely valid since they should enter into force well ahead of the present proposal.

Nevertheless, the subsequent introduction of the definitive arrangements for B2B supplies of goods as foreseen in the present proposal does require the adaptation to these new arrangements of the provisions contained in the Directive (EU) 2018/1910 regarding the concept of CTP (if finally adopted, see Section 3.2.1), call-off stocks or chain transactions.

In addition, since the objective of the present proposal is to introduce the definitive arrangements for B2B supplies of goods, the proposed Article 402, which sets out the cornerstones for the taxation of trade between Member States, covering goods and services, needs to be adapted to the fact that these cornerstones are partially put into effect by this proposal.

75. In the view of assessing the impact on smaller businesses, a distinction has been made between SMEs that are engaged predominantly in domestic trade and SMEs that are already engaged in both domestic and intra-EU trade. For this second category of SMEs, the proposed changes, and in particular the broadening of the scope of the one stop shop mechanism, could result in an average annual reduction of up to $17 \%$ compared to their current VAT compliance costs. However, the Impact Assessment accompanying the specific proposal on $\operatorname{SME}(\operatorname{SWD}(2018) 9$ final and $\operatorname{SWD}(2018) 11$ final), should result in a reduction of VAT compliance costs of up to $18 \%$ (or EUR 11.9 billion) for SMEs and an increase in SMEs' cross-border trading activity of about $13 \%$.
In addition, this proposal provides the opportunity to replace the outdated notions of 'Intra-Community' or 'Community' by the notions of 'Intra-Union' and 'Union' in a range of provisions of the VAT Directive.

The recent Commission proposal concerning the special scheme for small enterprises ${ }^{76}$ also requires a few technical updates such as the aforementioned replacement in the light of the present proposal. To avoid ambiguity, these changes are not included in the present proposal but shall be handled during the negotiations in Council.

\subsection{Detailed Explanation of the Specific Provisions of the Proposal}

The main substantial changes proposed to the VAT Directive are explained hereafter by topic. These substantial changes do result in a number of subsequent amendments of a technical nature in the VAT Directive.

\subsubsection{Subject Matter and Scope of the Tax: Articles 2-4}

The current VAT system splits cross-border B2B supply of goods into two different transactions for VAT purposes: an exempt supply in the Member State of departure of the goods and an intra-Community acquisition taxed in the Member State of destination. It is proposed that a cross-border B2B supply of goods within the Union will give rise to a single transaction for VAT purposes: an intra-Union supply of goods. Consequently, the concept of an intra-Community acquisition of goods as a transaction subject to VAT is to be removed from Articles 2 to 4 .

Since an intra-Community acquisition of goods would no longer exist as a transaction subject to VAT, all subsequent provisions within the VAT Directive related to that concept need to be deleted and to be reviewed in the light of the proposed mechanism for taxing the cross-border B2B trade in goods within the Union.

\subsubsection{The Concept of Intra-Union Supplies of Goods: Article 14(4)(3)}

It is proposed to add a point (3) to paragraph 4 of Article $14,{ }^{77}$ which contains a definition of intra-Union supplies of goods. 'Intra-Union supply of goods' shall mean a supply of goods carried out by a taxable person for a taxable person or for a non-taxable legal person (see also Section 4.2.6) whereby the goods are dispatched or transported, by or on behalf of the supplier or the person acquiring the goods within the Union, from one Member State to another Member State.

Certain supplies enumerated in paragraph 5 of Article 14 are not to be regarded as intra-Union supplies, even when the two conditions for qualifying, namely as regards the status of the customer and as regards the transport of the goods, would be fulfilled. This is the case for:

- supplies of goods with assembly or installation, with or without a trial run;

- supplies of goods that are exempt under Article 148 or 151 ; and

76. $\operatorname{COM(2018)} 21$ final, of 18 January 2018

77. As introduced by Directive 2017/2455, see Section 2.2.3.1. 
- supplies by a flat-rate farmer defined in Article 295.

\subsubsection{The Rules on the Place of Supply of Goods: Article $35 a$}

The rules on the place of supply of taxable transactions determine the Member State in which VAT is due. The general rules for determining the place of supply of goods without transport (the place where the goods are located at the time the supply takes place) and the place of supply of goods with transport (the place where the goods are located when dispatch of the goods or transport begins) remain. However, a new exception to the general rule is proposed in Article 35a, according to which the place of supply of an intra-Union supply of goods shall be deemed to be the place where the goods are located at the time when dispatch or transport of the goods to the customer ends.

The combination of the definition of intra-Union supplies of goods in Article 14(4)(3), see Section 4.2.2, and the new proposed place of supply rule in Article $35 \mathrm{a}$ ensures the taxation of a cross-border B2B supply of goods within the Union in the Member State of destination.

Under the current VAT rules, cross-border supplies to taxable persons who carry out only supplies of goods or services in respect of which VAT is not deductible, to taxable persons subject to the common flat-rate scheme for farmers and to non-taxable legal persons are, below a certain threshold and when the acquirer did not opt for taxation at destination, still taxed at the Member State of supply (origin).

This exception adds to the complexity of the current arrangements. It has also lost some of its relevance since the threshold has never been reviewed since its implementation in 1993. This exception is therefore not retained also because, contrary to the current situation, under the proposed rules the supplier will take care of the reporting and payment obligations related to these supplies.

Taxation at destination is thereby ensured for all intraUnion B2B supplies of goods. The only exception is the supplies made under the margin scheme provided for in Articles 311 and onwards (Art. 35c). Further taxation at destination will not apply either for the cross-border supplies of goods that are exempt under Article 148 or 151 and for the cross-border supplies of goods by a flatrate farmer defined in Article 295 since, as indicated in Section 4.2.2, they are excluded from the notion of intra-Union supplies of goods.

\subsubsection{Chargeability of the Tax: Article 67}

An amendment to Article 67 is proposed that determines a single rule for the chargeability of VAT on intra-Union supplies. According to this rule, VAT shall become chargeable on issue of the invoice or on expiry of the time limit referred to in the first paragraph of Article 222 if no invoice has been issued by that time (fifteenth day of the month following that in which the chargeable event occurs).
It is further specified that those provisions allowing Member States to determine, in certain cases, different moments of chargeability of VAT shall not apply with respect to intra-Union supplies of goods. In the absence of this specification, the supplier making intra-Union supplies in several Member States would have to comply with the options taken by the different Member States of arrival of the goods, which would increase complexity.

\subsubsection{Person Liable for Payment of VAT: Articles 193, $194 a, 199 a$ and 1996}

The principle laid down in Article 193 remains that VAT shall be payable by any taxable person carrying out a taxable supply of goods or services, unless in other provisions, enumerated in that same Article 193, it is stipulated that VAT is payable by another person.

As an exception to Article 193, a new Article 194a is proposed, according to which VAT shall be payable by the person to whom the goods are supplied insofar as he is a CTP as defined in Article 13a if the goods are supplied by a taxable person not established within the territory of the Member State in which the VAT is due. The concept of CTP was included in the Commission's proposal of 4 October 2017; see Section 3.2, but not yet adopted, see Section 3.2.1.

As regards intra-Union supplies of goods, the combination of the rules of Articles 193 and 194a means that the supplier is in principle liable for the payment of the VAT in the Member State of arrival of the goods except where the supplier is not established in the Member State of taxation and the customer is a CTP according to Article $13 \mathrm{a}$. In the latter case, the customer will pay the VAT due by way of reverse charge in the Member State of arrival of the goods.

Article 199a allows Member States to provide until 31 December 2018, for certain supplies specified in this provision, that the person liable for payment of VAT shall be the taxable person to whom these supplies are made.

In the recently adopted report on the effects of Article 199a and $199 \mathrm{~b}$ on combating fraud, ${ }^{78}$ the Commission indicated that it will present an appropriate legislative proposal for prolonging the existing measures, adopted as Directive (EU) 2018/1695. The Directive covers the period from 1 January 2019 until 30 June 2022, given that the envisaged date of entry into force of the present proposal is 1 July 2022.

The amendments of Article 199a proposed hereafter relate to the period from 1 July 2022 onwards. They concern the time span and the scope of the supplies covered.

As regards the time span, it is proposed to extend the option to make use of this provision until 31 December 2028. The other dates laid down in this provision are adapted accordingly.

78. Report from the Commission to the Council and the European Parliament on the effects of Art. 199a and 199b of Council Directive 2006/112/EC on combating fraud, $\operatorname{COM}(2018) 118$ final. 
As regards the supplies to be included in this provision, it is obvious that the proposed content has to be assessed in the context of the overall change of the taxation of the cross-border movement of B2B supplies of goods. The proposed changes intend to provide a fundamental response to cross-border fraud relating to transactions in goods and should therefore make the existing patchwork of temporary reverse charge measures in Article 199a, to the extent to which they also aim to give a response to this kind of fraud, redundant. The transactions that remain covered by the temporary measures of Article $199 \mathrm{a}$ are therefore limited to those services previously covered in this provision.

A comparable approach is suggested for the amendment of Article 199b. This provision lays down the rules governing the Quick Reaction Mechanism, which allows Member States in very specific circumstances to designate the recipient of the goods and services as the person liable for VAT. For the same reason as in Article 199a, supplies of goods would no longer be covered by the Quick Reaction Mechanism.

\subsubsection{Identification: Article 214}

Intra-Union supplies of goods, defined in Article 14, paragraph 4 , point 3 , include, inter alia, supplies made by a taxable person to a non-taxable legal person, see Section 4.2.2.

An amendment to Article 214 is therefore proposed, according to which Member States shall take the measures necessary to ensure that a non-taxable legal person who is the recipient of an intra-Union supply is identified by means of an individual number.

\subsubsection{Recapitulative Statements: Articles 262-271}

Intra-Union supplies of goods under the proposed system should no longer be included in the recapitulative statements. The principle of VAT being charged by the supplier on the intra-Union supply re-installs the self-policing character of VAT. Consequently, ensuring an administrative follow-up to the physical flow of goods through the recapitulative statement within the Union is no longer justified.

When the recipient of an intra-Union supply is a CTP, goods will continue to circulate VAT free within the Union. Nevertheless, it would be incoherent with the concept of a CTP, which is considered to be a reliable taxable person, to maintain the obligation of submitting recapitulative statements for such transactions.

The obligation to submit recapitulative statements is therefore only maintained for services.

Member States may introduce, under certain conditions, special measures to simplify the obligation to submit recapitulative statements. It is proposed to simplify the procedure for taking up this option, by replacing the requirement of a unanimous decision from the Council by a consultation of the VAT Committee.

\subsubsection{Special Schemes for Non-established Taxable Persons: Articles 358-369x}

Chapter 6 of Title XII of the VAT Directive currently contains three schemes with a distinctive scope, namely:
- a special scheme for services supplied by taxable persons not established within the Union;

- a special scheme for intra-Union distance sales of goods and for services supplied by taxable persons within the Union but not in the Member State of consumption;

- a special scheme for distance sales of goods imported from third territories or third countries.

The first and third schemes are only marginally affected by this proposal.

In view of implementing the principle of a single registration scheme for declaration, payment and deduction of the tax, substantial changes to the second scheme are proposed.

\subsubsection{The Special Scheme for Intra-Union Distance} Sales of Goods and for Services Supplied by

Taxable Persons within the Union But Not in the Member State of Consumption

Taking into account the adoption by the Council of Directive (EU) 2017/2455 of 5 December $2017,{ }^{79}$ this second scheme will, as of 1 January 2021, allow the taxable person registered for the scheme in a Member State (the Member State of identification) to electronically submit quarterly mini One-Stop-Shop VAT returns detailing supplies of services and intra-Union distance sales to non-taxable persons in other Member States (the Member State(s) of consumption), along with the VAT due. These returns, along with the VAT paid, are then transmitted by the Member State of identification to the corresponding Member States of consumption via a secure communications network. This scheme avoids that these taxable persons need to be registered for VAT in each Member State of consumption. The current proposal provides for a further extension of this scheme. As regards the definitions used for the purposes of this scheme, a definition of 'Member State of taxation' is added in Article 369a. Member State of taxation means the Member State in which the supply of goods or services is deemed to take place.

The scope of transactions covered by the scheme, set out in Article 369b, is amended. It is proposed that the option to make use of the scheme should be available to any taxable person not established in the Member State of taxation in relation to the supplies of goods and services made in that Member State for which he is liable to pay value added tax. It will thereby no longer be limited to Business-to-Consumer transactions but also include $\mathrm{B} 2 \mathrm{~B}$ transactions.

It is proposed to make the scheme also available to taxable persons not established within the Union under the condition that they appoint an intermediary that is established in the Union. Comparable to what is already foreseen in the special scheme for distance sales of goods imported from third territories or third countries, the 
intermediary is the person that becomes liable for the payment of the VAT and for fulfilling the obligations laid down in the scheme in the name and on behalf of the non-EU established taxable person he represents.

Considering the widening of the scope of transactions covered by the scheme, it is proposed to amend Article $369 \mathrm{f}$ by adding that taxable persons making use of the scheme shall submit monthly One-Stop-Shop VAT returns when their annual EU turnover is above EUR 2,500,000.

Article $369 \mathrm{~g}$, which defines the content of the VAT return to be submitted under the scheme, also needs to be reviewed. Currently, the information to be provided only relates to the value and the VAT due on supplies made by the taxable persons.

Including the right for the taxable person to exercise the deduction of input VAT in the One-Stop-Shop VAT return is possible only when some additional information is provided in that return and in particular:

- the total amount of VAT that has become chargeable on supplies of goods and services for which the taxable person as recipient is liable to pay the tax and on the importation of goods where the Member State exercises the option under the second paragraph of Article 211;

- the VAT for which deduction is made;

- amendments relating to previous tax periods;

- the net amount of the VAT to pay or to be refunded or credited.

Since deduction will be made on the VAT returns submitted through the scheme, an amendment to Article $369 \mathrm{i}$ is proposed that stipulates that the taxable person shall pay the sum of the net amounts of VAT (VAT due minus VAT deductible) due in each Member State of taxation.

A new Article 369ia is proposed defining the conditions under which a taxable person in a credit position in a given Member State of taxation can obtain a refund of the credit from that Member State. Moreover, a new Article $369 \mathrm{ib}$ is proposed that determines the conditions under which an amount to be refunded to the taxable person in the Member State of identification can be used for the payment of VAT due in the Member State(s) of taxation.

An amendment to Article $369 \mathrm{j}$ is proposed in order to determine the interaction between the right to deduct under the special scheme and the refund procedures laid down in (the Thirteenth) Directive 86/560/EEC for taxable persons not established in the Union and Directive 2008/9/EC (replacing the Eighth Directive) for taxable persons established in the Union. This provision is necessary in order to avoid potential abuse by taxable persons that would exercise a right to deduct under the special scheme and would submit a request for refund for the same amount of input VAT.

In principle a taxable person has the right to make the deduction of the input VAT on the VAT returns submitted through the scheme. However, when a taxable person making use of this special scheme does not make any supplies of goods and services covered by this special scheme for which VAT has become chargeable in a Member State of taxation in a given tax period, nor in the three preceding tax periods when he is submitting quarterly returns or in the eleven preceding tax periods when he is submitting monthly returns, no deduction of VAT incurred may be made in that Member State of taxation in that VAT return. Instead of that, the taxable person should claim the input VAT back via the refund procedure in the Member State in which VAT was charged.

\subsubsection{Derogations: Articles 370-390c}

Chapter 1 of Title XIII of the VAT Directive contains a series of derogations that may be applied until the adoption of the definitive arrangements. For those States that were Member States on 1 January 1978, most of the derogations they may apply are spelled out in Annex X to the VAT Directive. As explained earlier, the present proposal is the first step in the process of putting the definitive system of taxation of intra-EU trade at destination into place. As part of this step, it is proposed to delete those derogations for which, if they were maintained, the proposed changes of the place of supply rules and of the designation of the person liable for payment of VAT would lead to complexity for the taxable persons and the tax administrations.

In particular, the option to apply a derogation would be suppressed for goods that could be the object of intraUnion supplies (movable goods). In that case, the supplier would have to know, for each Member State in which these intra-Union supplies take place, whether that Member State made use of the derogation or not and, if so, which are the conditions applied by those Member States.

\section{Closing Remarks}

The EU VAT system also exists for more than fifty years and over the years it has proven to be an effective, stable and relatively easy means of tax collection on consumption. It, however, is clear that the EU VAT system needed a refresh to make it simpler, more fraud-proof and business-friendlier. Not least because of the rise in e-commerce. Terra shows in this article how the European Commission is paving the way towards a more robust EU VAT system. It becomes evident that this process can be best described as the ordeal of indirect tax harmonisation and that we are only half-way there, the proposal for the Definitive VAT system ${ }^{80}$ still pending.

80. $\operatorname{COM}(2017) 569$ final. 